\title{
Investigating Research Streams of Conjoint Analysis: A Bibliometric Study
}

Thorsten Teichert, Chair of Marketing and Innovation, University of Hamburg, E-mail: teichert@econ.uni-hamburg.de Edlira Shehu, Hamburger Sparkasse AG, Hamburg, E-mail: edashehu@yahoo.de

\begin{abstract}
Conjoint analysis (CA) is one of the most important methods for preference elicitation. In this paper we investigate the intellectual structure within the conjoint analytical research community. Analyses based on single papers provide a method-based overview of streams of conjoint research. By using novel bibliometric techniques in this field we complement findings of existing reviews. We use co-citation and factor analysis of the most cited articles in SSCI to identify the most important articles and research streams. Seven research streams are revealed which are visualized by means of multidimensional scaling. Tables and graphics reveal the disciplinary affiliations of contributors to CA, the special structure within the classes as well as links between them.
\end{abstract}

Keywords: conjoint analysis, bibliometric analysis

Manuscript received March 11, 2009, accepted by Adamantios Diamantopoulos (Marketing) January 28, 2010

\section{$1 \quad$ Introduction}

Once a scientific discipline has reached a certain maturity, its scholars turn their attention towards the literature generated by the scientific community. Reviews of the existing literature are performed to assess the state of the art. This provides future researchers with valuable guidance for conducting and positioning their own studies. At the same time, it helps established scholars in the field assess their own contributions in relation to developments occurring within the overall research field. Finally, such a review serves to integrate different research streams and thus counteracts tendencies of dispersion stemming from single research works.

Conjoint analysis (CA) is one of the most important methods of marketing research and practice. A wide variety of applications are labelled as "Conjoint", which however are not necessarily based on a common methodological concept (Hauser and Rao 2004). The method is thus characterized by a discrepancy between external relevance and a lack of internal coherence. Accordingly, the purpose of this paper is to jointly consider the various research streams of CA in order to provide an overall picture of this method. We want to provide insights about the foundations of the different research streams, their developments over time as well as their interconnections. Given that the method of CA has increasingly spread both in its scope of application areas as well as in its methodological foundations, we perceive a need for such an overview.

Existing review articles on conjoint analysis (CA) provide separate discussions about distinct approaches in isolation (e.g., Green and Srinivasan 1978, 1990; Louviere, Eagle, and Cohen 2005; Hauser and Rao 2004). Our analysis aims to complement these existing reviews on conjoint analysis by providing an overall picture of the entire research field, its driving forces as well as its interconnections.

We make use of bibliometric approaches for revealing prominent research streams in the scientific discourse as well as their proximities and chronological relevance for the conjoint analytical community. This provides us objective measures not only about the impact of research contributions and their 
interrelations, but also on how this method has evolved over time (White and McCain 1998). By combining quantitative bibliometric and factor analytical approaches with qualitative interpretations of the research streams at a single level publication, our analysis complements existing overviews on conjoint analysis which are based either on methodical aspects (e.g., Green and Srinivasan 1990) or on application aspects (Wittink and Cattin 1989; Cattin and Wittink 1982).

Bibliometric analysis is an established tool for the investigation of structural patterns within published literature (White 2004). It is used for discovering hidden "scientific communities" in which members of academic fields interact and draw on each other's findings (Jarneving 2005, 2008; Tahai and Meyer 1999). Especially in recent research, it has been successfully applied in the analysis of different business subdisciplines, such as, e.g., consumer research (Leong 1989), innovation management (Teichert 2004) or operations management research (Pilkington and Meredith 2009). In a more narrow perspective, it has also been applied to investigate the discourses within specific journals, e.g., Journal of Consumer Research (Hoffman and Holbrook 1993) or Strategic Management Journal (RamosRodriguez and Ruiz-Navarro 2004). Whereas a main focus of these bibliometric analyses lay in rankings or mapping of entire disciplines or journals (e.g., Baumgartner and Pieters 2003), it has also been applied to investigate specific discourses of interest in more detail (e.g., Pilkington and Teichert 2006): Here, one was able to reveal substantial differences of the research agenda of international scholars, which partly explain delays experienced in developing technology management as a respected academic discipline. In line with this recent research, our paper transfers this method to an investigation of the conjoint analytical discourse. Among others, we want to identify research streams and possible missing links of coherence in the discourse in order to provide recommendations for future research.

The paper is divided into five sections: First, we briefly introduce the methodology of bibliometric analysis. The following section presents and discusses the descriptive results of a citation analysis. The third section investigates the overall scientific discourse by means of co-citation analysis. Key issues of identified research streams are discussed in section four. A summary and suggestions for future research conclude this paper.

\section{Methodological Background}

Based upon the insight that scientific progress evolves cumulatively and that followers base their work "On the Shoulders of Giants" (Merton 1965), citations are seen as symbolic payments of intellectual debt in the formal publication system. Bibliometric analysis investigates these structural patterns and thus reveals interrelationships between ideas, authors and "the intellectual structure of scholarly fields" (White 1990). Based on the underlying assumption that closely related works are frequently cited together by referencing papers, bibliometric analysis is a valuable tool for the analysis of scientific discourses (Culnan 1986; Hoffman and Holbrook 1993; Tahai and Meyer 1999). In broader terms (e.g., Lievrow 1990), bibliometrics is defined as the application of mathematical and statistical methods to books and any other media of communication.

The study of references, publications and citations is important in tracing the intellectual growth of a certain application or method. The most intuitive indicator is the number of published papers from one author (Tahai and Meyer 1999). Another level of analysis makes use of data pertaining the frequency with which various authors are cited in the literature (McKain 1990). Frequency counts by various categories of interest can be aggregated, such as key journals in a certain discipline (Zinkhan, Roth, and Saxton 1992). An alternative approach is counting numbers of citations of a certain journal from journals of alternative disciplines (Cote, Leong, and Cote 1991). Citation analysis is based on the premise that authors cite documents they consider to be important for their research. Therefore, frequently cited authors are likely to have exerted a greater influence on the discipline than those less frequently cited (Garfield 1979). This basic idea, whilst variously refined (Bar-Ilan 2008), still builds the basis for analyses on the impact of authors, institutions or journals.

As the above-referenced phrase of the "Giants" states, followers regularly base their work not only on a single but on multiple sources. Contributions which are perceived to be related are likely to be cited together. This pattern of co-recognition is the basic idea of co-citation analysis (Small 2004), 
which was introduced in 1973 by Small as "the frequency with which two documents are cited together". Unlike bibliometric coupling (Jarneving 2005) which links source documents, co-citation links cited documents and is therefore analogous to a measure of association. Co-citation strength reveals the degree of relationship or association between papers as perceived by the population of cited authors considered. Starting from the assumption that the bibliographic references cited in research papers are a reliable indication of their influence, co-citation analysis can identify the most influential documents and analyze the relational links between them. Accordingly, co-citation analysis has been repeatedly used successfully to map the intellectual structure of academic disciplines (e.g., Pilkington and Meredith 2009; Baumgartner and Pieters 2003).

\section{Figure 1: Stepwise approach applied for co- citation analysis}

Identify publications on CA in SSCi (1960-2006)
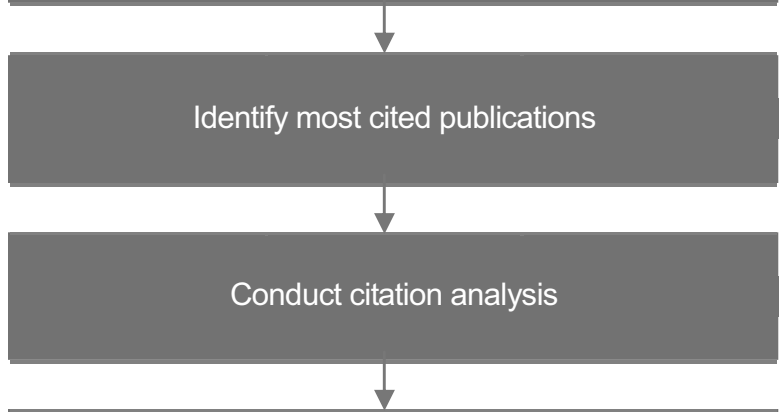

Retrieve co-citation counts for each pair of publications

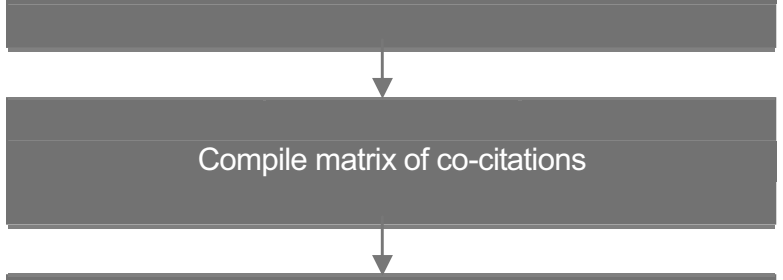

Perform following analysis:

1. Factor analysis for identifying research streams

2. MDS for graphically mapping stream proximities

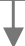

Interpret the results and stream based discussion
To conclude, citation and co-citation patterns provide complementary information about the evolution of science (Small 2004): Whereas citations identify major ideas, co-citation reveals the relationships between them. We thus perform a state-ofthe-art, step-wise analysis (Nerur, Rasheed, and Natarajan 2008) to gain in-depth insights about the scientific discourses and their relationships (Figure 1). Both the data input as well as the evaluation procedure are carefully selected based on the specific objectives of our study.

Concerning the data input, we perform a co-citation analysis on the level of single publications in order to analyze relations among specific conceptual ideas or empirical findings. This disaggregated view is needed since many authors who have contributed in the establishment of conjoint analysis have worked on different aspects of this method. By aggregating the information and conducting an author cocitation analysis this information would be lost and the development path of conjoint analysis would not be clearly visualized.

Method-wise, a combination of factor analysis and MDS is applied to analyse the co-citation data. This combination has proven to be highly efficient in order to identify themes, concepts and relationships (e.g., Teichert 2004; Ma, Lee, and Yu 2008; Nerur, Rasheed, and Natarajan 2008). Factorial analysis techniques by themselves constitute a method commonly applied to separate research streams (Culnan, O'Reilly, and Chatman 1990; Pilkington and Meredith 2009; Ponzi 2002). Using factoranalytical measures, prominent publications and their influence are analyzed within each research stream.

Complementary hereto, a subsequent multidimensional scaling (MDS) provides a graphical representation of the proximities of discourses. (Please note that within this paper we reversed the order of result presentations for reading ease.) This combination of well-established statistical tools has been shown to be especially useful as it provides an intuitive overview to the reader by joining complementary information (Biehl, Kim, and Wade 2006). Alternatively, Hult and Chabowski (2008) solely rely on MDS maps and use the standardized distance between each article to calculate clusters. We do not follow this approach as it foregoes the possibility of cross-validation between two independent methods. Specific algorithms such as, e.g., a logmultiplicative model (Pieters, Baumgartner, Ver- 
munt, and Bijmolt 1999) did not seem needed as the data matrices were of limited size and as we were not interested in specific issues of, e.g., self-citations or impact measures.

Furthermore, we interpret factor loadings as well as factor scores as complementary indicators on relevance and embeddedness of single publications within each research stream. The novel, finegrained analyses on the level of single publications allow us to reveal interfaces between fields, knowledge flows at topical levels, and trends at microlevels (Boyack, Börner, and Klavans 2009). The additional differentiation into two time periods provides a dynamic view on the evolution of research discourses (Small 2006). It allows to track the emergence and growth of specific research areas, hinting as well towards upcoming changes. To conclude, we analyze the overall patterns related to each stream by discussing overlaps and differences of the streams. Here, one has to keep in mind that the applied factor analytical method cannot provide insights about the interrelations between research streams as it aims for solutions of maximal independence. Thus, we refer back to the raw data and investigate the interrelations between articles of different research streams based on their positioning gained from multidimensional scaling.

\section{Bibliometric Descriptives}

Our data basis encompasses a broad set of scientific journal publications on the topic of CA. Bibliometric data provided by the Social Science Citation Index (Web of Science) build the basis for our study. This large-scale, highly reputed data base can be considered as "certified knowledge" (Ramos-Rodriguez and Ruiz-Navarro 2004). To obtain a representative data set, we consider all articles on CA in SSCI. A search for the keywords "conjoint" yielded 1510 results (2006-08-22). The results were refined by constricting the search to the key words "CA" or "conjoint measurement" yielding 807 results (same date). The 703 articles which were not included in the second search process were investigated more closely in order to judge their affinity to the method of CA. As the major part did not show any relationship to the method of CA we identified an additional 88 articles which used the conjoint analytical approach. These articles' titles did not contain the denomination $\mathrm{CA}$, but key words such as "conjoint analytical" functions etc. were used. We identified 895 publications that are related to CA. These articles together with their bibliometric information constitute our data base for further analysis.

The 895 articles were published within 109 different fields of research. Business and management research are the most prominent research areas with respectively $27 \%$ and $14 \%$, followed by applications in the area of economics and health care (see Table 1). One can observe a large heterogeneity both in the outlets of single contributions as well as in their foundations: The publications in our data set stem from 589 different first authors and 309 different journals, $73 \%$ of them are marketing journals. The citations provided in these articles even stem from 8.256 journal sources.

Table 1: Research areas of retrieved articles

\begin{tabular}{lrc}
\hline $\begin{array}{l}\text { Subject Category } \\
\text { (according to SSCI) }\end{array}$ & $\begin{array}{r}\text { Record } \\
\text { Count }\end{array}$ & $\%$ \\
\hline Business & 238 & $26.6 \%$ \\
\hline Management & 128 & $14.3 \%$ \\
\hline Economics & 112 & $12.5 \%$ \\
\hline Health Care Sciences and Services & 76 & $8.5 \%$ \\
\hline $\begin{array}{l}\text { Operations Research and Manage- } \\
\text { ment Science }\end{array}$ & 72 & $8.0 \%$ \\
\hline $\begin{array}{l}\text { Social Sciences, Mathematical Meth- } \\
\text { ods }\end{array}$ & 64 & $7.2 \%$ \\
\hline Health Policy and Services & 61 & $6.8 \%$ \\
\hline $\begin{array}{l}\text { Mathematics, Interdisciplinary } \\
\text { Applications }\end{array}$ & 54 & $6.0 \%$ \\
\hline Psychology, Mathematical & 52 & $5.8 \%$ \\
\hline Environmental Studies & 38 & $4.2 \%$ \\
\hline
\end{tabular}

Several data preparation steps were needed before conducting citation analyses. Retrieved citation information had to be examined carefully in order to avoid duplicate items caused, e.g., by different spellings of author names or different citation styles. In such cases, the citation information (e.g., times cited) were aggregated, so that every cited article only appears once in our data base. Citation data were then used to retrieve insights into the relevance of contributions at the journal, author and single publication level. Two complementary indicators were used: The number of citations received by 
Table 2: Most cited CA contributions at journal, author and publication level

\begin{tabular}{|c|c|c|c|c|c|c|c|c|}
\hline $\begin{array}{l}10 \text { most referenced } \\
\text { Journals (sorted by CA- } \\
\text { Focus }=\text { CR/CT) }\end{array}$ & $\mathbf{C R}$ & TC & $\begin{array}{l}\text { 10 most referenced } \\
\text { Authors (sorted by } \\
\text { CA-Focus }=\text { CR/CT) }\end{array}$ & $\mathbf{C R}$ & TC & $\begin{array}{l}9 \text { most referenced Publica- } \\
\text { tions (sorted by CA-Focus } \\
=\mathrm{CR} / \mathrm{CT} \text { ) }\end{array}$ & $\mathbf{C R}$ & $\mathbf{T C}$ \\
\hline Psychometrika & 227 & 67 & Krantz, D. H. & 157 & 61 & $\begin{array}{l}\text { Green, P. E. et al. 1981, Journal } \\
\text { of Marketing }\end{array}$ & 78 & 97 \\
\hline $\begin{array}{l}\text { Journal of Environmental } \\
\text { and Economic Management }\end{array}$ & 236 & 102 & Fishburn, P. C. & 170 & 74 & $\begin{array}{l}\text { Wittink, D. R. 1989, Journal of } \\
\text { Marketing }\end{array}$ & 109 & 137 \\
\hline Management Science & 599 & 270 & Srinivasan, V. & 150 & 93 & $\begin{array}{l}\text { Green, P. E. et al. 1990, Journal } \\
\text { of Marketing }\end{array}$ & 194 & 271 \\
\hline $\begin{array}{l}\text { Journal of Consumer Re- } \\
\text { search }\end{array}$ & 896 & 682 & Wittink, D. R. & 272 & 192 & $\begin{array}{l}\text { Ryan, M. et al. 1998, Health } \\
\text { Economics }\end{array}$ & 67 & 94 \\
\hline $\begin{array}{l}\text { Journal of Marketing Re- } \\
\text { search }\end{array}$ & 2140 & 1866 & Louviere, J. J. & 424 & 303 & $\begin{array}{l}\text { Cattin, P. et al. 1982, Journal of } \\
\text { Marketing }\end{array}$ & 110 & 155 \\
\hline Marketing Science & 572 & 509 & Johnson, R. M. & 179 & 179 & $\begin{array}{l}\text { Green, P. E. et al. 1978, Journal } \\
\text { of Consumer Research }\end{array}$ & 281 & 569 \\
\hline Health Economics & 336 & 355 & Cattin, P. & 170 & 172 & $\begin{array}{l}\text { Green, P. E. et al. 1971, Journal } \\
\text { of Marketing Research }\end{array}$ & 112 & 239 \\
\hline Journal of Marketing & 986 & 1268 & Ryan, M. & 323 & 337 & $\begin{array}{l}\text { Louviere, J. J. et al. 1983, Jour- } \\
\text { nal of Marketing Research }\end{array}$ & 68 & 201 \\
\hline Psychology Review & 270 & 355 & Green, P. E. & 1375 & 1581 & $\begin{array}{l}\text { Luce, R. D. et al. 1964, Journal } \\
\text { of Mathematical Psychology }\end{array}$ & 123 & 413 \\
\hline $\begin{array}{l}\text { Journal of Mathematical } \\
\text { Psychology }\end{array}$ & 469 & 732 & Luce, R. D. & 294 & 474 & & & \\
\hline
\end{tabular}

$C A=$ Conjoint analysis, $C R=$ Citations received,$T C=$ Times cited

our extracted set of conjoint articles indicates the relevance of a journal (author/publication) for providing specific methodological foundations in the field of CA. In contrast, the overall count of received SSCI citations indicates the relevance of this journal (author/publication) to topics reaching beyond conjoint analysis, i.e. any mode of applications. An index is thus built by dividing the number of times cited within our CA data base (TC-CA) by the total times cited in SSCI (TC-SSCI). High values indicate a focus on CA methodology whereas low values indicate references in broad areas of application. We calculate these citation indices at a journal, author and single publication level. Please note that the indices should not be interpreted separately from the underlying raw measures, as a high focus may well coincide with a small number of citations (example, an index of 1 need not imply a high impact, as it may stem in the very extreme from a single citations within the same field).

At the journal level, our index provides insights into the positioning of respective journals (Table 2): Journals with strictly methodical contribution such as Psychometrika and Management Science reveal a relatively high internal impact within the CA discourse. The Journal of Consumer Research and the Journal of Marketing Research possess average index values as they publish both methodical- and application-based conjoint studies. Journals such as the Journal of Mathematical Psychology and Health Economy have the smallest index values as conjoint is only one among numerous methods that are applied for investigating branch-related problems.

At the author level, the calculated index allows to assess the positioning of key authors within the CA discourse. The highest ranks of CA Focus in Table 2 show that the conjoint-internal discourse is the main outlet for authors researching on axiomatic conjoint measurement, such as the authors Krantz and Fishburn. Authors who have investigated methodological as well as application aspects are ranked in the middle positions, whereas authors who have mainly applied the method, e.g., Ryan in health sciences, have a much smaller conjoint focus, since their findings are mainly cited in content-related articles. 
Finally, a citation analysis can be performed on the level of single publications (Table 2). As expected, famous review articles are listed among the nine most cited papers (Wittink and Cattin 1989; Green and Srinivasan 1978, 1990; Cattin and Wittink 1982). Furthermore, we find the founding article of choice-based conjoint (Louviere and Woodworth 1983) as well as the methodological foundation of the axiomatic conjoint measurement (Luce and Tukey 1964), both however with lowest relative impact within the conjoint analytical community: These seminal works with interdisciplinary character are found a big echo beyond the community itself. The famous article of Green and Rao (1971) drew upon the conjoint measurement theory from Luce and Tukey and adapted it to the solution of marketing and product development problems, carefully considering the measurement issues and opened a number of research opportunities and applications. Finally, the article of Green, Goldberg, and Montemayor (1981) stands out in terms of percentage of citations from conjoint-related articles. This seems plausible since this is one of the first papers using CA to derive market share estimates for product optimization: New product development has become one of the most important application fields of conjoint. Consequently, this article is referred to from various publications in this field.

\section{The Research System}

Co-citation analysis which links cited documents (Small 1973) has been successfully used to map the intellectual structure of academic disciplines. The method is based on the notion that documents which are related to each another will, in general, be repeatedly cited together in subsequent publications while documents which are rarely or never cited together do not (Jarneving 2005). Thus, the closeness of contributions is algorithmically related to their similarity as perceived by citers (McCain 1990).

A standard approach often used in bibliographic analysis is to concentrate on cited authors as a proxy for their ideas, amalgamating all their publications together (Culnan 1986). We follow the procedures firstly recommended by White and Griffith (1981) and still used as state-of-the-art-approach (Nerur, Rasheed, and Natarajan 2008), but with the added precision of using single publication level rather than aggregated author level as in most bibliometric studies. In order to focus the analyses on the most prominent articles, we conduct co-citation analysis for the top 5\% of cited papers (Teichert 2004; even more restrictive (top 1\%): Small 2006). Co-citations of these 147 works were tabulated for each of the 895 source documents. The counts are arranged on

Figure 2: The overall research system

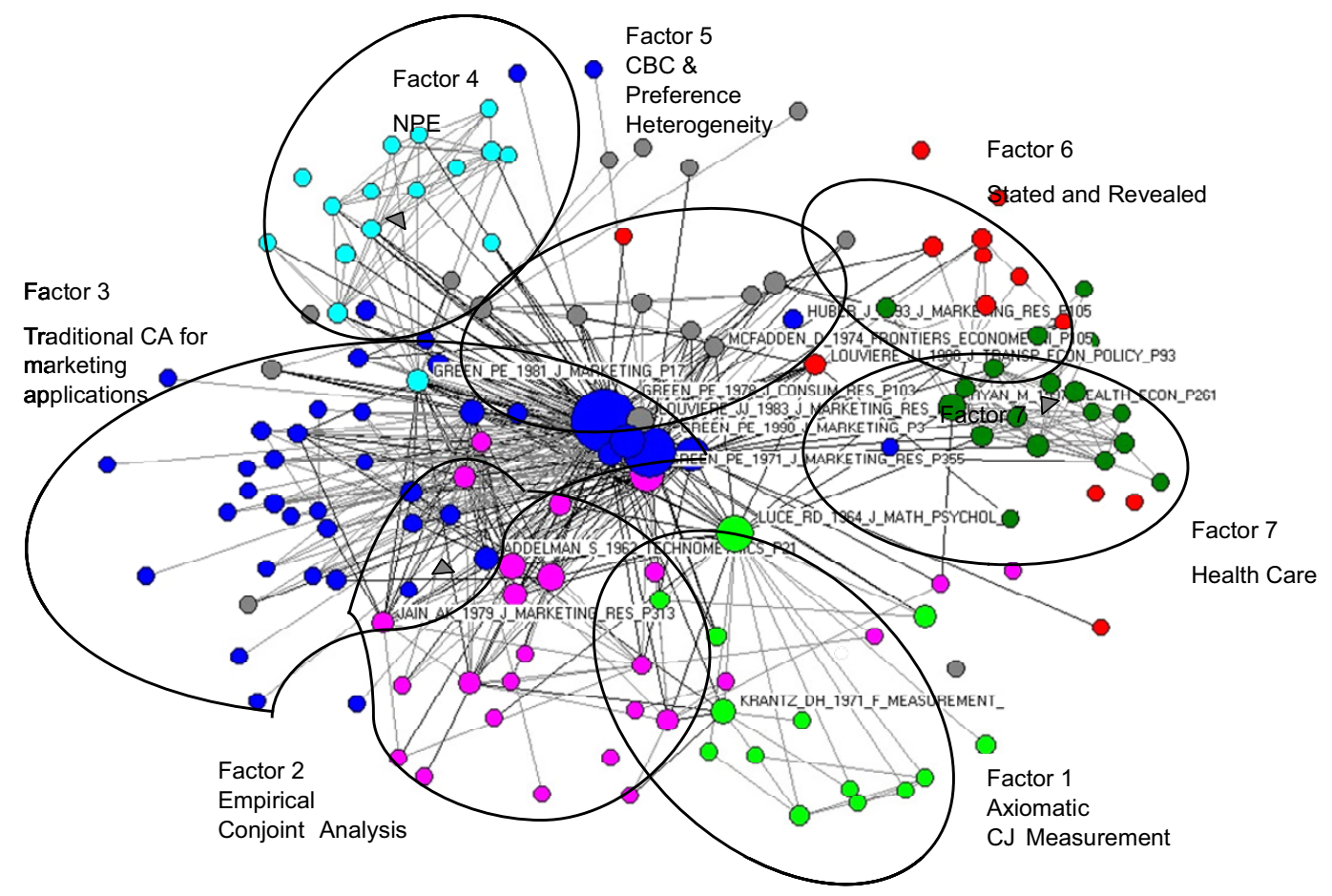


a symmetrical 147-by-147 co-citation matrix. This matrix then served as data input for a traditional factor analysis applying the Ward procedure with Varimax rotation. In line with White and Griffith (1981), a few adaptations were performed to ensure the applicability of this approach: Specifically, we replaced the diagonal elements by the sum of the three highest scores divided by two. Based on a scree test, seven factors with Eigenvalues above one were revealed which account for $71 \%$ of the variance of the co-citation matrix. Less than 30\% (3\%) loaded on two (three) factors with factor loadings slightly above 0.4, hinting towards limited factual overlap between the discourses.

Before we present the in-depth findings gained from the factor analysis, we provide a first visualization of the overall research system. We present the most important articles (Figure 2) by means of a multidimensional scaling procedure provided by the network analytical software UCINET (Borgatti, Everett, and Freeman 2002). For ease of viewing, only articles and their interconnections are displayed that are co-cited six times or more. Circles represent single articles whereas lines represent co-citations. Articles are arranged according to their interconnections. Thus, more selective or loosely linked cocitation patterns appear on the periphery of the chart. Articles are colour-coded according to their factor-analytic allocation (see in-depth results below) to seven different factors, circle dimensions are added to indicatively visualize the spatial position of these underlying research streams (see details of the upfront-executed factor analysis in subsequent section). Light-coloured connection lines represent cocitations within the respective factors. Co-citations between the factors are represented by dark lines.

The graph shows the dominance of Green as the most distinguished author. His article of 1971 adapts conjoint measurement for marketing applications, introducing the method of empirical CA. Furthermore, his two prominent review articles together with Srinivasan are the centre of the overall research system and serve as central junctions between all factors. In addition, the article of Luce and Tukey (1964) stands out. This work shows to serve as a "linking pin" between three factors, which are revealed by the factor analysis below: axiomatic conjoint measurement, empirical conjoint analyses as its successor and marketing applications of CA. Thus, it can be considered to have constituted the theoretical foundation of conjoint analysis.
In the upper right of the figure, the work of Louviere and Woodworth (1983) possesses a prominent position serving as connector between traditional and choice based conjoint discourses. In a similar vein, McFadden's early work (1974) on conditional logit joins the two factors of modelling and applying choice based conjoint. This nicely visualizes the role of McFadden as the "father" of conditional logit modelling and as one of the most prominent researchers in discrete choice modelling.

\section{$5 \quad$ Research Streams and Key Issues}

A factor analysis supports the prima-facie classification of co-citations in scientific discourses and enables a quantitative evaluation of the relative impact of single articles within the discovered discourses. For this purpose, key measures of factor analysis are translated into the context of co-citation analysis. The variance extracted by a factor signals the relative breadth of a discourse in relation to the overall research stream. Factor loadings and factor scores deliver complementary information: While factor loadings show how one publication fits into the overall context of one discourse (factor), factor scores reversely indicate how much the respective discourse is influenced from this publication. By setting both measures into comparison, one can gain additional hints towards the contribution of publications: Both measures generally correlate as this indicates correspondence of influence and integration into the discourse. An article reveals an especially broad and far-reaching positioning, when it exerts a relatively high impact on a discourse (high factor score), but is not as much represented by the discourse (lower factor loading). Vice versa, an article seems to be narrowly embodied into a discourse if it is highly represented by latter (high factor loading) while it does not impact the discourse as much (lower factor score).

Tables 3-9 display the results of the factor analysis in detail. For ease of interpretation, the factors are not sorted by their relative explained variance but based on content considerations. The percentages of explained variance are provided and discussed as well. The tables list each article, its corresponding factor score (FS) and factor loading (FL). Factor scores indicate the importance of an article for the respective research discourse. The greater the factor score, the more prominent an article is within the 
respective research stream. Taking a reciprocal perspective, factor loadings near one indicate that the co-citation occurrences of an article are fully explained by the factor, i.e. the contribution of the article seems perfectly represented by the particular research stream. Smaller values indicate connections to other research streams or a broader research agenda. A third column sets both measures in relation. For this, the relative ranks of factor loadings as well as factor scores are compared. If these two ranking positions deviate by five or more ranks, a marker is set to " $\geq$ " (“s”), in order to indicate an especially broad (narrow) reflection of the article.

The first factor (Table 3) explains the smallest percentage of variance (3.3\%) and comprises publications focused on utility modelling with axiomatic conjoint measurement. The most central article (FS=5.78) of Luce and Tukey (1964) establishes the foundation of the psychometric utility measurement. It is complemented by Krantz and Tverskys (1971) elaborations on the foundations of measurement. The impact of these two "Giants" work goes well above and beyond the conjoint-specific discourse, which is indicated by the difference between their high factor score and relatively low factor loadings. In a more narrowly focused perspective, Debreu (1960), Tversky (1969), and Roberts (1979) examine different basic aspects of psychometric utility measurement. Such aspects are also the topic of future work such as decision conflicts (Tversky and Shafir 1992), prospect theory (Kahneman and Tversky 1979), additivity, and intransitivity (Fishburn 1970). These researchers have set up the basic model propositions of conjoint measurement, which provide the conceptual basis for the application orientated CA.

The second factor which is also the second-largest factor with $13 \%$ explained variance comprises works which transmitted the conceptual foundations of conjoint measurement to the practical CA (Table 4). It thus is labelled as empirical preference elicitation with $C A$. The articles mainly date back to the early 70 and are published in a wider spectrum of journals than those of the first factor. While later application-related articles mainly focus on marketing issues we find within this factor articles with interdisciplinary connections to psychology, operations research as well as behavioural aspects. Remarkable are several articles published in Psychometrika, one of the leading journals in methodical developments that emphasize the referenced focus of methodical development and establishment. Works of Kruskal (1965), Krantz and Tversky (1971) and, more narrowly focused (see FS $<$ FL), Srinivasan and Shocker (1973) are important milestones of the methodical foundation of conjoint.

\section{Table 3: Discourse on axiomatic conjoint measurement (Factor 1)}

\begin{tabular}{|c|c|c|c|}
\hline $\begin{array}{l}\text { Prominent Articles } \\
\text { (sorted by descending FS) }\end{array}$ & FS & FL & $\begin{array}{l}\Delta \text { Ranks } \\
\text { FS } \rightarrow \text { FL }\end{array}$ \\
\hline $\begin{array}{l}\text { Luce, R. D. et al. 1964, Journal } \\
\text { of Mathematical Psychology }\end{array}$ & 5.78 & .61 & $\geq$ \\
\hline $\begin{array}{l}\text { Krantz, D. H. et al. 1971, Foun- } \\
\text { dation of Measurement }\end{array}$ & 3.50 & .72 & $\geq$ \\
\hline $\begin{array}{l}\text { Fishburn, P. C. 1970, Utility } \\
\text { Theory for Decision Making }\end{array}$ & 3.10 & .86 & $\approx$ \\
\hline $\begin{array}{l}\text { Wakker, P. P. 1989, Additive } \\
\text { Representations of Preferences: } \\
\text { a New Foundation of Decision } \\
\text { Analysis }\end{array}$ & 3.09 & .88 & $\approx$ \\
\hline $\begin{array}{l}\text { Scott, D. 1964, Journal of } \\
\text { Mathematical Psychology }\end{array}$ & 3.04 & .84 & $\approx$ \\
\hline $\begin{array}{l}\text { Debreu, G. 1960, Mathematical } \\
\text { Methods in the Social Sciences }\end{array}$ & 2.88 & .87 & $\leq$ \\
\hline $\begin{array}{l}\text { Tversky, A. 1969, Psychological } \\
\text { Review }\end{array}$ & 2.72 & .87 & $\leq$ \\
\hline $\begin{array}{l}\text { Kahneman, D. et al. 1979, } \\
\text { Econometrica }\end{array}$ & 2.51 & .68 & $\approx$ \\
\hline $\begin{array}{l}\text { Roberts, F. S. 1979, Measure- } \\
\text { ment Theory }\end{array}$ & 1.94 & .85 & $\leq$ \\
\hline $\begin{array}{l}\text { Keeney, R. L. et al. 1976, Deci- } \\
\text { sions with Multiple Objectives }\end{array}$ & 1.86 & .64 & $\approx$ \\
\hline $\begin{array}{l}\text { Krantz, D. H. 1964, Journal of } \\
\text { Mathematical Psychology }\end{array}$ & 1.76 & .71 & $\approx$ \\
\hline $\begin{array}{l}\text { Falmagne, J. C. 1976, Psycholo- } \\
\text { gical Review }\end{array}$ & 1.38 & .63 & $\approx$ \\
\hline $\begin{array}{l}\text { Luce, R. D. 1959, Individual } \\
\text { Choice Behavior }\end{array}$ & 1.27 & .46 & $\approx$ \\
\hline
\end{tabular}

$F S=$ Factor score,$F L=$ Factor loading

The most prominent author within this factor is Green. Once again, this shows his dominating position in methodical as well as application conjoint issues. Based on, but still detached from the discourse on axiomatic conjoint measurement documented in the first factor, Green's contribution "operates" as a transmission mechanism by developing and presenting pragmatic approaches for conjoint applications. 
Table 4: Discourse on preference elicitation with CA (Factor 2)

\begin{tabular}{|c|c|c|c|}
\hline $\begin{array}{l}\text { Prominent Articles } \\
\text { (sorted by descending FS) }\end{array}$ & FS & FL & $\begin{array}{l}\Delta \text { Ranks } \\
\text { FS } \rightarrow \text { FL }\end{array}$ \\
\hline $\begin{array}{l}\text { Kruskal, J. B. 1965, Journal of the Royal } \\
\text { Statistical Society }\end{array}$ & 3.75 & 0.86 & $\approx$ \\
\hline $\begin{array}{l}\text { Green, P. E. et al. 1971, Journal of Market- } \\
\text { ing Research }\end{array}$ & 3.18 & 0.66 & $\geq$ \\
\hline $\begin{array}{l}\text { Green, P. E. et al. 1973, Multiattribute } \\
\text { Decisions in Marketing }\end{array}$ & 2.96 & 0.89 & $\approx$ \\
\hline $\begin{array}{l}\text { Johnson, R. M. 1974, Journal of Market- } \\
\text { ing Research }\end{array}$ & 2.75 & 0.75 & $\geq$ \\
\hline $\begin{array}{l}\text { Green, P. E. 1974, Journal of Consumer } \\
\text { Research }\end{array}$ & 2.66 & 0.78 & $\approx$ \\
\hline Srinivasan, V. et al. 1973, Psychometrika & 2.58 & 0.74 & $\geq$ \\
\hline $\begin{array}{l}\text { Krantz, D. H. et al. 1971, Psychological } \\
\text { Review }\end{array}$ & 2.25 & 0.75 & $\approx$ \\
\hline Parker, B. R. 1976, Operations Research & 2.16 & 0.81 & $\approx$ \\
\hline $\begin{array}{l}\text { Dawes, R. M. et al. 1974, Psychological } \\
\text { Bulletin }\end{array}$ & 1.6 & 0.73 & $\geq$ \\
\hline $\begin{array}{l}\text { Carmone, F. J. et al. 1978, Journal of } \\
\text { Marketing Research }\end{array}$ & 1.56 & 0.63 & $\geq$ \\
\hline $\begin{array}{l}\text { Green, P. E. et al. 1975, Harvard Business } \\
\text { Review }\end{array}$ & 1.53 & 0.62 & $\geq$ \\
\hline $\begin{array}{l}\text { Jain, A. K. et al. 1979, Journal of Market- } \\
\text { ing Research }\end{array}$ & 1.51 & 0.65 & $\approx$ \\
\hline $\begin{array}{l}\text { Davidson, J. D. 1973, Operational Re- } \\
\text { search Quarterly }\end{array}$ & 1.45 & 0.82 & $\leq$ \\
\hline $\begin{array}{l}\text { Ullrich, J. R. et al. 1974, Organizational } \\
\text { Behavior and Human Performance }\end{array}$ & 1.32 & 0.74 & $\leq$ \\
\hline $\begin{array}{l}\text { Anderson, N. H. 1981, Foundations of } \\
\text { Information Theory }\end{array}$ & 1.17 & 0.54 & $\geq$ \\
\hline Srinivasan, V. et al. 1973, Psychometrika & 1.14 & 0.74 & $\leq$ \\
\hline $\begin{array}{l}\text { Green, P. E. et al. 1972, Behavioural } \\
\text { Sciences }\end{array}$ & 1.12 & 0.78 & $\leq$ \\
\hline Johnson, R. M. 1975, Psychometrika & 1.11 & 0.85 & $\leq$ \\
\hline Emery, D. R. et al. 1979, Psychometrika & 1.02 & 0.59 & $\approx$ \\
\hline $\begin{array}{l}\text { Anderson, N. H. 1982, Methods of Infor- } \\
\text { mation Integration Theory }\end{array}$ & 0.92 & 0.52 & $\approx$ \\
\hline $\begin{array}{l}\text { Wind, Y. et al. 1976, Operational Research } \\
\text { Quarterly }\end{array}$ & 0.81 & 0.64 & $\leq$ \\
\hline $\begin{array}{l}\text { Anderson, N. H. 1970, Psychological } \\
\text { Review }\end{array}$ & 0.56 & 0.56 & $\approx$ \\
\hline $\begin{array}{l}\text { McCullough, J. et al. 1979, Journal of } \\
\text { Marketing Research }\end{array}$ & 0.37 & 0.59 & $\leq$ \\
\hline Lancaster, K. 1971, Consumer Demand & 0.26 & 0.47 & $\approx$ \\
\hline Tversky, A. 1972, Psychological Review & 0.25 & 0.42 & $\approx$ \\
\hline $\begin{array}{l}\text { Chapman, R. G. et al. 1982, Journal of } \\
\text { Marketing Research }\end{array}$ & 0.14 & 0.41 & $\approx$ \\
\hline
\end{tabular}

$F S=$ Factor score,$F L=$ Factor loading
Green's research also plays a central role in the third factor that describes the utilization driven discourse on application of CA in marketing (Table 5). This factor dominates the entire CA discourse, as it explains nearly $30 \%$ of the entire variance in the cocitation matrix. The central position of the most cited articles by Green emphasizes once again the high relevance of his work for the establishment of conjoint in empirical marketing research. Especially his prominent reviews $(1978,1990)$ are often cited in this factor, whereby the highest factor scores within this factor $(\sim 4)$ reveal the high impact of both articles on the discourse. On the other hand, their relatively low factor loadings $(<.7)$ indicate that these articles are frequently cited even in other research fields beyond CA. Finally, the high frequency of co-citations shows a strong content relationship as well as complementarities of both articles and indicates the actuality of these works for present conjoint-related research.

Central reviews especially focusing on the diffusion of $\mathrm{CA}$ in practice and commercial studies are also assigned to this third factor. We find the collaborations of Cattin and Wittink (1982, 1989) who were the first to deliver descriptive reviews on the state of the art of conjoint applications in commercial studies. Both studies influence the discourse within this factor as characterized by especially high factor scores. This may suggest that the diffusion of CA is based mainly on imitation factors, thus partially showing tendencies of being a "management" method in marketing research.

In general, methodical articles assigned to this publication do not focus on conceptual issues, but rather on practical issues of conjoint applications. The article by Addelman (1962) on the generation of efficient experimental designs is therefore outstanding. The relevance of design efficiency is also highlighted by the article of Johnson (1987) which introduced ACA as an approach for taking a large number of attribute levels into account. This article has the highest factor loading in this discourse which indicates that handling design complexity has been of upmost importance for the diffusion of conjoint in commercial studies. Further methodical contributions such as the method of hybrid CA (Green, Goldberg, and Montemayor 1981; Green 1984) and individual conjoint estimations (Green and Helsen 1989) show early approaches for solving specific critical issues. These include a large number of attributes and preference heterogeneity that are 
Table 5: Discourse on applications of CA in marketing (Factor 3)

\begin{tabular}{|c|c|c|c|}
\hline $\begin{array}{l}\text { Prominent Articles } \\
\text { (sorted by descending FS) }\end{array}$ & FS & FL & $\begin{array}{l}\Delta \text { Ranks } \\
\text { FS } \rightarrow \text { FL }\end{array}$ \\
\hline $\begin{array}{l}\text { Green, P. E. et al. 1978, Journal of } \\
\text { Consumer Research }\end{array}$ & 4.73 & .69 & $\geq$ \\
\hline $\begin{array}{l}\text { Green, P. E. et al. 1990, Journal of } \\
\text { Marketing }\end{array}$ & 3.89 & .67 & $\geq$ \\
\hline $\begin{array}{l}\text { Green, P. E. et al. 1984, Journal of } \\
\text { Marketing Research }\end{array}$ & 2.84 & .81 & $\approx$ \\
\hline $\begin{array}{l}\text { Cattin, P. et al. 1982, Journal of Mar- } \\
\text { keting }\end{array}$ & 2.74 & .64 & $\geq$ \\
\hline $\begin{array}{l}\text { Wittink, D. R. et al. 1989, Journal of } \\
\text { Marketing }\end{array}$ & 2.36 & .65 & $\geq$ \\
\hline $\begin{array}{l}\text { Green, P. E. et al. 1981, Journal of } \\
\text { Marketing }\end{array}$ & 2.24 & .76 & $\geq$ \\
\hline $\begin{array}{l}\text { Johnson, R. M. 1987, Sawtooth Soft- } \\
\text { ware }\end{array}$ & 2.06 & .85 & $\leq$ \\
\hline $\begin{array}{l}\text { Leigh, T. W. et al. 1984, Journal of } \\
\text { Marketing Research }\end{array}$ & 2.02 & .81 & $\leq$ \\
\hline $\begin{array}{l}\text { Hagerty, M. R. 1985, Journal of Mar- } \\
\text { keting Research }\end{array}$ & 1.78 & .79 & $\approx$ \\
\hline $\begin{array}{l}\text { Srinivasan, V. et al. 1983, Journal of } \\
\text { Marketing Research }\end{array}$ & 1.53 & .78 & $\approx$ \\
\hline $\begin{array}{l}\text { Moore, W. L. 1980, Journal of Market- } \\
\text { ing Research }\end{array}$ & 1.48 & .77 & $\approx$ \\
\hline $\begin{array}{l}\text { Reibstein, D. et al. 1988, Marketing } \\
\text { Science }\end{array}$ & 1.38 & .80 & $\leq$ \\
\hline $\begin{array}{l}\text { Cattin, P. et al. 1983, Journal of Mar- } \\
\text { keting Research }\end{array}$ & 1.29 & .77 & $\leq$ \\
\hline $\begin{array}{l}\text { Kamakura, W. A. 1988, Journal of } \\
\text { Marketing Research }\end{array}$ & 1.28 & .68 & $\geq$ \\
\hline $\begin{array}{l}\text { Wittink, D. R. 1981, Journal of Mar- } \\
\text { keting Research }\end{array}$ & 1.25 & .70 & $\approx$ \\
\hline $\begin{array}{l}\text { Green, P. E. et al. 1989, Journal of } \\
\text { Marketing Research }\end{array}$ & 1.23 & .83 & $\leq$ \\
\hline Srinivasan, V. 1988, Decision Sciences & 1.22 & .73 & $\leq$ \\
\hline $\begin{array}{l}\text { Green, P. E. et al. 1979, Journal of } \\
\text { Marketing }\end{array}$ & 1.20 & .75 & $\leq$ \\
\hline $\begin{array}{l}\text { Hagerty, M. R. 1986, Marketing Sci- } \\
\text { ence }\end{array}$ & 1.18 & .79 & $\leq$ \\
\hline $\begin{array}{l}\text { Akaah, I. P. et al. 1983, Journal of } \\
\text { Marketing Research }\end{array}$ & 1.14 & .73 & $\leq$ \\
\hline $\begin{array}{l}\text { Wittink, D. R. et al. 1994, Internatio- } \\
\text { nal Journal of Research in Marketing }\end{array}$ & 1.13 & .63 & $\geq$ \\
\hline Addelman, S. 1962, Technometrics & 1.05 & .62 & $\geq$ \\
\hline $\begin{array}{l}\text { Green, P. E. et al. 1991, Journal of } \\
\text { Marketing }\end{array}$ & .92 & .63 & $\geq$ \\
\hline $\begin{array}{l}\text { Green, P. E. 1991, Journal of Con- } \\
\text { sumer Research }\end{array}$ & .89 & .67 & $\leq$ \\
\hline $\begin{array}{l}\text { Desarbo, W. S. et al. 1992, Marketing } \\
\text { Letters }\end{array}$ & .81 & .60 & $\geq$ \\
\hline
\end{tabular}

\begin{tabular}{lcccc}
\hline $\begin{array}{l}\text { Prominent Articles continued } \\
\text { (sorted by descending FS) }\end{array}$ & FS & FL & $\begin{array}{l}\Delta \text { Ranks } \\
\text { FS } \rightarrow \text { FL }\end{array}$ \\
\hline $\begin{array}{l}\text { Wittink, D. R. et al. 1982, Journal of } \\
\text { Consumer Research }\end{array}$ & .78 & .73 & $\leq$ \\
\hline $\begin{array}{l}\text { Louviere, J. J. 1988, Analyzing Deci- } \\
\text { sion Making }\end{array}$ & .77 & .57 & $\geq$ \\
\hline $\begin{array}{l}\text { Punj, G. et al. 1983, Journal of Mar- } \\
\text { keting Research }\end{array}$ & .71 & .64 & $\leq$ \\
\hline $\begin{array}{l}\text { Huber, J. et al. 1993, Journal of Mar- } \\
\text { keting Research }\end{array}$ & .70 & .63 & $\approx$ \\
\hline $\begin{array}{l}\text { Wind, Y. 1978, Journal of Marketing } \\
\text { Research }\end{array}$ & .65 & .59 & $\approx$ \\
\hline $\begin{array}{l}\text { Payne, J. W. 1976, Organizational } \\
\text { Behavior and Human Performance }\end{array}$ & .60 & .64 & $\leq$ \\
\hline $\begin{array}{l}\text { Green, P. E. et al. 1988, Journal of } \\
\text { Consumer Research }\end{array}$ & .54 & .69 & $\leq$ \\
\hline $\begin{array}{l}\text { Wilkie, W. L. et al. 1973, Journal of } \\
\text { Marketing Research }\end{array}$ & .52 & .58 & $\approx$ \\
\hline $\begin{array}{l}\text { Page, A. L. et al. 1987, Journal of Prod- } \\
\text { uct Innovation Management }\end{array}$ & .47 & .60 & $\approx$ \\
\hline $\begin{array}{l}\text { Mahajan, V. et al. 1982, Journal of } \\
\text { Marketing Research }\end{array}$ & .44 & .58 & $\approx$ \\
\hline $\begin{array}{l}\text { Haley, R. I. 1968, Journal of Market- } \\
\text { ing }\end{array}$ & .40 & .55 & $\approx$ \\
\hline $\begin{array}{l}\text { Silk, A. J. et al. 1978, Journal of Mar- } \\
\text { keting Research }\end{array}$ & $<.40$ & .66 & $\leq$ \\
\hline $\begin{array}{l}\text { Plackett, R. L. et al. 1946, Biometrika } \\
\text { Tversky, A. et al. 1988, Psychological } \\
\text { Review }\end{array}$ & $<.40$ & .48 & $\approx$ \\
\hline $\begin{array}{l}\text { Hair, J. F. et al. 1998, Multivariate } \\
\text { Data Analysis }\end{array}$ & $<.40$ & .41 & $\geq$ \\
\hline $\begin{array}{l}\text { Parasuraman, A. et al. 1985, Journal } \\
\text { of Marketing }\end{array}$ & $<.40$ & .45 & $\approx$ \\
\hline $\begin{array}{l}\text { Fishbein, M. et al. 1975, Belief, Atti- } \\
\text { tude, Intention, Behavior }\end{array}$ & $<.40$ & .48 & $\approx$ \\
\hline
\end{tabular}

$F S=$ Factor score,$F L=$ Factor loading

still part of the present discourse. Furthermore, we find a continuing discourse on cross-validation of self-explicating versus CA approaches in this factor (Leigh, MacKay, and Summers 1984).

Summing up, the third factor includes foundations of preference elicitation with CA. It is characterized by the pursuit of applying conjoint for realistic problems with large designs and by applying challenging estimation methods. Early answers are presented for unresolved problems which are still part of the present conjoint analytical discourse.

The fourth factor (Table 6) which explains $7 \%$ of the total variance comprises articles on $C A$ in new product development and positioning. The article by Green, Goldberg, and Montemayor (1981) which 
introduces CA as a prominent method for optimizing new products and for conducting market simulations is one of the most central publications within this cluster ( $\mathrm{FS}=2.95)$. Given the broad positioning of this article, it is more unidirectionally exerting an influence on the discourse while reaching above and beyond it ( $\mathrm{FS}>\mathrm{FL})$. Other, more-into-the-discourse embedded articles investigate application issues of traditional $\mathrm{CA}$, e.g., for the evaluation of product concepts (Shocker and Srinivasan 1974, 1979). As opposed to the model-driven traditional CA that mainly assumes linear-additive utility functions, this discourse contains research that applies heuristic optimizations of new products (Kohli and Krishnamurthi 1987, 1989) as well as product lines (Kohli and Sukumar 1990; McBride and Zufryden 1988). Early solutions are refined in later approaches by using genetic or evolutionary algorithms. These recent articles are however not shown in the cocitation analysis, since co-citation analysis has a retrospective character.

The fifth factor (6\% explained variance) focuses on modelling aspects of choice based conjoint and preference heterogeneity. There are two streams of research within this factor (Table 7): Firstly, we can identify a discourse on modelling preference heterogeneity, e.g., by using hierarchical Bayes models (Allenby and Rossi 1999; Lenk, DeSarbo, Green, and Young 1996; Allenby, Arora, and Ginter 1995, 1998). The high factor scores of the respective articles indicate the high impact of such research work within the contemporary context. High factor loadings stress the embeddedness into the methodical advancements in the present scientific discourse.

A second stream of research comprises publications investigating choice-based conjoint (CBC) issues. These works root back to Louviere and Woodworth (1983) who established the underlying concepts of $\mathrm{CBC}$ by combining conjoint analytical elements with aspects of discrete choice models. Subsequent articles examine different aspect of $\mathrm{CBC}$ such as generating experimental designs (Huber and Zwerina 1996; Carson, Louviere, Anderson, Arabie, Bunch, Hensher, Johnson, Krahfeld, Steinberg, Swait, Timmermans, and Wiley 1994) or cross-validation of CBC with other conjoint approaches (Vriens, Oppewal, and Wedel 1998; Elrod, Louviere, and Davey 1992). The works of McFadden (1974) and, even more broadly referenced (FS $>\mathrm{FL}$ ), Ben-Akiva and Lerman (1985) establish a methodical foundaion of discrete choice theory that supports the feasibility and statistical analysis of empirical studies.

Table 6: Discourse on CA in new product development and positioning (Factor 4)

\begin{tabular}{|c|c|c|c|}
\hline $\begin{array}{l}\text { Prominent Articles } \\
\text { (sorted by descending FS) }\end{array}$ & FS & FL & $\begin{array}{l}\Delta \text { Ranks } \\
\text { FS } \rightarrow \text { FL }\end{array}$ \\
\hline $\begin{array}{l}\text { Green, P. E. et al. 1985, Market- } \\
\text { ing Science }\end{array}$ & 3.93 & .95 & $\approx$ \\
\hline $\begin{array}{l}\text { Kohli, R. et al. 1990, Manage- } \\
\text { ment Science }\end{array}$ & 3.83 & .94 & $\approx$ \\
\hline $\begin{array}{l}\text { Green, P. E. et al. 1989, European } \\
\text { Journal of Operational Research }\end{array}$ & 3.30 & .92 & $\geq$ \\
\hline $\begin{array}{l}\text { McBride, R. D. et al. 1988, } \\
\text { Marketing Science }\end{array}$ & 3.29 & .93 & $\approx$ \\
\hline $\begin{array}{l}\text { Dobson, G. et al. 1993, Manage- } \\
\text { ment Science }\end{array}$ & 3.16 & .93 & $\approx$ \\
\hline $\begin{array}{l}\text { Green, P. E. et al. 1981, Journal } \\
\text { of Marketing }\end{array}$ & 2.95 & .65 & $\geq$ \\
\hline $\begin{array}{l}\text { Kohli, R. et al. 1987, Manage- } \\
\text { ment Science }\end{array}$ & 2.81 & .92 & $\approx$ \\
\hline $\begin{array}{l}\text { Green, P. E. et al. 1992, Market- } \\
\text { ing Science }\end{array}$ & 2.58 & .93 & $\leq$ \\
\hline $\begin{array}{l}\text { Nair, S. K. et al. 1995, Manage- } \\
\text { ment Science }\end{array}$ & 2.55 & .93 & $\leq$ \\
\hline $\begin{array}{l}\text { Dobson, G. et al. 1988, Market- } \\
\text { ing Science }\end{array}$ & 2.49 & .92 & $\approx$ \\
\hline $\begin{array}{l}\text { Shocker, A. D. et al. 1979, Jour- } \\
\text { nal of Marketing Research }\end{array}$ & 2.05 & .74 & $\approx$ \\
\hline $\begin{array}{l}\text { Shocker, A. D. et al. 1974, Man- } \\
\text { agement Science }\end{array}$ & 2.01 & .86 & $\approx$ \\
\hline $\begin{array}{l}\text { Hauser, J. R. et al. 1988, Harvard } \\
\text { Business Review }\end{array}$ & 1.50 & .81 & $\approx$ \\
\hline $\begin{array}{l}\text { Urban, G. L. et al. 1993, Design } \\
\text { and Marketing of New Products }\end{array}$ & .84 & .72 & $\approx$ \\
\hline Wind, J. et al. 1989, Interfaces & .69 & .49 & $\approx$ \\
\hline $\begin{array}{l}\text { Griffin, A. et al. 1993, Marketing } \\
\text { Science }\end{array}$ & .69 & .45 & $\approx$ \\
\hline
\end{tabular}

$F S=$ Factor score,$F L=$ Factor loading

Design issues of choice-based conjoint and revealed preferences (Table 8) are the common focus of articles grouped in factor six (7.4\% explained variance). Modelling issues of stated (Louviere, 1988) as well as revealed choices (Adamowicz, Swait, Boxall, Louviere, and Williams 1997; Hensher 1994; Swait and Louviere 1993) are discussed here. Research communities, such as Louviere, Hensher, and Swait (2000) or Swait and Louviere (1993), explain the 
high frequencies of co-citations within the factor. These collaborations provide interdisciplinary links to a discourse which uses choice modelling for examining agricultural and environmental issues (Adamowicz, Swait, Boxall, Louviere, and Williams 1997; Adamowicz, Louviere, and Williams 1994). Furthermore, the review article of Boxall, Adamowicz, Swait, Williams, and Louviere (1996) stands out, as it is especially embedded into this discourse $(\mathrm{FS}<\mathrm{FL})$ and thus may provide a good overview.

Table 7: Discourse on modelling aspects of CBC and preference heterogeneity (Factor 5)

\begin{tabular}{|c|c|c|c|}
\hline $\begin{array}{l}\text { Prominent Articles } \\
\text { (sorted by descending FS) }\end{array}$ & FS & FL & $\begin{array}{l}\Delta \text { Ranks } \\
\text { FS } \rightarrow \text { FL }\end{array}$ \\
\hline $\begin{array}{l}\text { Lenk, P. J. et al. 1996, Marketing } \\
\text { Science }\end{array}$ & 4.21 & .83 & $\approx$ \\
\hline $\begin{array}{l}\text { Louviere, J. J. et al. 1983, Journal } \\
\text { of Marketing Research }\end{array}$ & 4.01 & .69 & $\geq$ \\
\hline $\begin{array}{l}\text { Kuhfeld, W. F. et al. 1994, Jour- } \\
\text { nal of Marketing Research }\end{array}$ & 2.84 & .82 & $\approx$ \\
\hline $\begin{array}{l}\text { Ben-Akiva, M. et al. 1985, Dis- } \\
\text { crete Choice Analysis }\end{array}$ & 2.74 & .66 & $\geq$ \\
\hline $\begin{array}{l}\text { Huber, J. et al. 1996, Journal of } \\
\text { Marketing Research }\end{array}$ & 2.56 & .79 & $\approx$ \\
\hline $\begin{array}{l}\text { Allenby, G. M. et al. 1995, Journal } \\
\text { of Marketing Research }\end{array}$ & 2.53 & .77 & $\approx$ \\
\hline $\begin{array}{l}\text { Allenby, G. M. et al. 1998, Jour- } \\
\text { nal of Marketing Research }\end{array}$ & 1.83 & .73 & $\approx$ \\
\hline $\begin{array}{l}\text { Allenby, G. M. et al. 1999, Journal } \\
\text { of Econometrics }\end{array}$ & 1.83 & .70 & $\approx$ \\
\hline $\begin{array}{l}\text { McFadden, D. 1974, Frontiers in } \\
\text { Econometrics }\end{array}$ & 1.78 & .64 & $\approx$ \\
\hline $\begin{array}{l}\text { Carroll, J. D. et al. 1995, Journal } \\
\text { of Marketing Research }\end{array}$ & 1.73 & .59 & $\geq$ \\
\hline $\begin{array}{l}\text { Elrod, T. et al. 1992, Journal of } \\
\text { Marketing Research }\end{array}$ & 1.50 & .64 & $\approx$ \\
\hline $\begin{array}{l}\text { Batsell, R. R. et al. 1991, } \\
\text { Marketing Letters }\end{array}$ & 1.47 & .67 & $\leq$ \\
\hline $\begin{array}{l}\text { Allenby, G. M. et al. 1995, Journal } \\
\text { of Marketing Research }\end{array}$ & 1.31 & .64 & $\approx$ \\
\hline $\begin{array}{l}\text { Carson, R. T. et al. 1994, } \\
\text { Marketing Letters }\end{array}$ & 1.15 & .64 & $\leq$ \\
\hline $\begin{array}{l}\text { Vriens, M. et al. 1996, Journal of } \\
\text { Marketing Research }\end{array}$ & 1.13 & .58 & $\approx$ \\
\hline $\begin{array}{l}\text { Oppewal, H. et al. } 1994 \text { Journal } \\
\text { of Marketing Research }\end{array}$ & 1.04 & .64 & $\leq$ \\
\hline $\begin{array}{l}\text { Saaty, T. L. 1980, The Analytic } \\
\text { Hierarchy Process }\end{array}$ & .27 & .44 & $\approx$ \\
\hline $\begin{array}{l}\text { Thurstone, L. L. 1927, Psycho- } \\
\text { logical Review }\end{array}$ & .27 & .43 & $\approx$ \\
\hline
\end{tabular}

$F S=$ Factor score, $F L=$ Factor loading
Table 8: Design issues of $\mathrm{CBC}$ and revealed preferences (Factor 6)

\begin{tabular}{|c|c|c|c|}
\hline $\begin{array}{l}\text { Prominent Articles } \\
\text { (sorted by descending FS) }\end{array}$ & FS & FL & $\begin{array}{l}\Delta \text { Ranks } \\
\text { FS } \rightarrow \text { FL }\end{array}$ \\
\hline $\begin{array}{l}\text { Louviere, J. J. 1988, Journal of } \\
\text { Transport Economics and Policy }\end{array}$ & 4.49 & 0.85 & $\approx$ \\
\hline $\begin{array}{l}\text { Adamowicz, W. et al. 1994, Jour- } \\
\text { nal of Environmental Economics } \\
\text { and Management }\end{array}$ & 4.05 & 0.82 & $\approx$ \\
\hline $\begin{array}{l}\text { Mackenzie, J. 1993, American } \\
\text { Journal of Agricultural Econom- } \\
\text { ics }\end{array}$ & 3.61 & 0.88 & $\approx$ \\
\hline $\begin{array}{l}\text { Roe, B. et al. 1996, Journal of } \\
\text { Environmental Economics and } \\
\text { Management }\end{array}$ & 3.4 & 0.84 & $\approx$ \\
\hline $\begin{array}{l}\text { Adamowicz, W. et al. 1997, Jour- } \\
\text { nal of Environmental Economics } \\
\text { and Management }\end{array}$ & 2.25 & 0.74 & $\approx$ \\
\hline $\begin{array}{l}\text { Opaluch, J. J. et al. 1993, Journal } \\
\text { of Environmental Economics and } \\
\text { Management }\end{array}$ & 2.16 & 0.64 & $\approx$ \\
\hline $\begin{array}{l}\text { Boxall, P. C. et al. 1996, Ecological } \\
\text { Economics }\end{array}$ & 1.78 & 0.85 & $\leq$ \\
\hline $\begin{array}{l}\text { Swait, J. et al. 1993, Journal of } \\
\text { Marketing Research }\end{array}$ & 1.57 & 0.58 & $\approx$ \\
\hline $\begin{array}{l}\text { Johnson, F. R. et al. 1997, Journal } \\
\text { of Environmental Economics and } \\
\text { Management }\end{array}$ & 1.48 & 0.73 & $\approx$ \\
\hline $\begin{array}{l}\text { Hensher, D. A. 1994, } \\
\text { Transportation }\end{array}$ & 1.38 & 0.7 & $\approx$ \\
\hline $\begin{array}{l}\text { Lancaster, K. J. 1966, The Jour- } \\
\text { nal of Political Economics }\end{array}$ & 1.06 & 0.62 & $\approx$ \\
\hline $\begin{array}{l}\text { Beggs, S. et al. 1981, Journal of } \\
\text { Econometrics }\end{array}$ & 0.96 & 0.56 & $\approx$ \\
\hline $\begin{array}{l}\text { Timmermans, H. et al. 1984, } \\
\text { Progress in Human Geography }\end{array}$ & 0.72 & 0.51 & $\approx$ \\
\hline $\begin{array}{l}\text { McFadden, D. 1986, Marketing } \\
\text { Sciences }\end{array}$ & 0.66 & 0.47 & $\approx$ \\
\hline
\end{tabular}

$F S=$ Factor score,$F L=$ Factor loading

In the last factor (Table 9) we find choice applications in health sciences. This factor explains nearly $10 \%$ of the total variance and is the third-largest factor even though it is less related to marketing applications. Extremely high factor loadings indicate an especially closed discourse. Thus, Ryan's work is almost perfectly representative for this research stream (Ryan and Hughes 1997; Ryan and Farrar 2000). Factor scores reveal Ryan and Brian as the most relevant authors within this factor. The complementary results of citation analysis further stress Ryan's relevance in conjoint applications in the health sector. Methodical contributions (Lou- 
viere, Hensher, and Swait 2000; McFadden 1974) serve as methodical foundations for these empirical applications. Relatively low factor loadings of these methodological works however indicate that their contributions are also highly relevant for research topics above and beyond the application context of health sciences. This holds especially true for the book of Louviere, Hensher, and Swait (2000), which is only marginally represented by the discourse as such $(\mathrm{FL}<\mathrm{FS})$.

\section{Overall Discourse Related to Research Streams}

To sum up the analysis, we investigate both the chronological impact as well as the relevance for contemporary research within the identified research streams. All 148 articles that were assigned to the research streams build the data basis.

Figure 3 presents an overview of the development of research streams over time. It can be seen that major contributions of axiomatic conjoint measurement and its empirical counterpart of traditional conjoint date quite far back in history. Thus, the discourses related to conceptual foundations of preference elicitation somehow lack new impulses. The discourse in general marketing seems to have reached its saturation phase as well since no toppublication is included in the data set after 1995 . Conjoint applications in new product development and positioning are shown to increase slightly. This may be due to ongoing improvement of methodical approaches such as fast polyhedral or genetic algorithms in single or line-based product optimizations. In contrast, contributions on choice-based conjoint are obviously still in their growth phase. Choice modelling and related design issues have undoubtedly been of prominent relevance for CA research in the last decade. Based on the revealed course of number of publications its potential seems not yet been exploited. The same tendency can be presumed for applications of choice-based conjoint in health care that only started about a decade ago.

To investigate structural differences between the discourses in more detail, we refer to two indices: The average publication year of articles belonging to one research stream serves as an index for the actuality of the research stream. Average citations counts of enclosed articles serve as indicator for the relevance of that factor for the entire conjoint analytical community (see Table 10). We utilize the information of both means and standard deviation, as it provides information about the typical discourse and its underlying homogeneity.

\section{Table 9: Choice applications in health sciences (Factor 7)}

\begin{tabular}{|c|c|c|c|}
\hline $\begin{array}{l}\text { Prominent Articles } \\
\text { (sorted by descending FS) }\end{array}$ & FS & FL & $\begin{array}{l}\Delta \mathbf{R a n k s} \\
\mathbf{F S} \rightarrow \mathbf{F L}\end{array}$ \\
\hline Ryan, M. et al. 1997, Health Economics & $5 \cdot 77$ & 0.97 & $\approx$ \\
\hline Bryan, S. et al. 1998, Health Economics & $4 \cdot 36$ & 0.96 & $\approx$ \\
\hline $\begin{array}{l}\text { Ryan, M. 1999, Social Science \& } \\
\text { Medicine }\end{array}$ & 4.04 & 0.96 & $\approx$ \\
\hline $\begin{array}{l}\text { Van Der Pol, M. et al. 1998, Journal of } \\
\text { Health Services }\end{array}$ & $3 \cdot 32$ & 0.95 & $\approx$ \\
\hline $\begin{array}{l}\text { Propper, C. 1995, Journal of Human } \\
\text { Resources }\end{array}$ & 3.24 & 0.93 & $\approx$ \\
\hline $\begin{array}{l}\text { Ryan, M. et al. 2000, British Medical } \\
\text { Journal }\end{array}$ & 2.36 & 0.9 & $\approx$ \\
\hline $\begin{array}{l}\text { Vick, S. et al. 1998, Journal of Health } \\
\text { Economics }\end{array}$ & 2.31 & 0.92 & $\approx$ \\
\hline $\begin{array}{l}\text { Ratcliffe, J. et al. 1999, International } \\
\text { Journal of Technical Assessment in } \\
\text { Health Care }\end{array}$ & 2.18 & 0.91 & $\approx$ \\
\hline $\begin{array}{l}\text { Bradley, M. 1991, Users' Manual for } \\
\text { Speed Version 2.1 Stated Preference } \\
\text { Editor and Designer }\end{array}$ & 2.16 & 0.91 & $\approx$ \\
\hline Ryan, M. et al. 1998, Health Economics & 1.71 & 0.85 & $\approx$ \\
\hline $\begin{array}{l}\text { McFadden, D. 1973, Conditional Logit } \\
\text { Analysis of Qualitative Choice Behaviour }\end{array}$ & 1.48 & 0.88 & $\approx$ \\
\hline Farrar, S. et al. 1999, Health Economics & 1.44 & 0.86 & $\approx$ \\
\hline $\begin{array}{l}\text { Louviere, J. J. et al. 2000, Stated Choice } \\
\text { Methods }\end{array}$ & 1.19 & 0.67 & $\geq$ \\
\hline $\begin{array}{l}\text { Magat, W. A. et al. 1988, Journal of } \\
\text { Environmental Economics and Man- } \\
\text { agement }\end{array}$ & 1.00 & 0.8 & $\approx$ \\
\hline $\begin{array}{l}\text { Mitchell, R. C. et al. 1989, Using Surveys } \\
\text { to Value Public Goods: the Contingent } \\
\text { Valuation Method }\end{array}$ & 0.9 & 0.72 & $\approx$ \\
\hline $\begin{array}{l}\text { Jan, S. 2000, Australian and New Zea- } \\
\text { land Journal of Public Health }\end{array}$ & 0.83 & 0.81 & $\approx$ \\
\hline $\begin{array}{l}\text { Johnson, F. R. et al. 2000, Health } \\
\text { Economics }\end{array}$ & 0.7 & 0.72 & $\approx$ \\
\hline $\begin{array}{l}\text { Wardman, M. 1988, Journal of Trans- } \\
\text { port Economics and Policy }\end{array}$ & 0.45 & 0.62 & $\approx$ \\
\hline
\end{tabular}

$F S=$ Factor score,$F L=$ Factor loading

Comparing the distribution of major contributions over time, the discourse on empirical preference elicitation (factor two) is characterized by the lowest standard deviation. This indicates a short period of time during which CA established itself as "succesor" of axiomatic conjoint measurement. Factors 
Figure 3: Cumulative distribution of the publications within the research streams

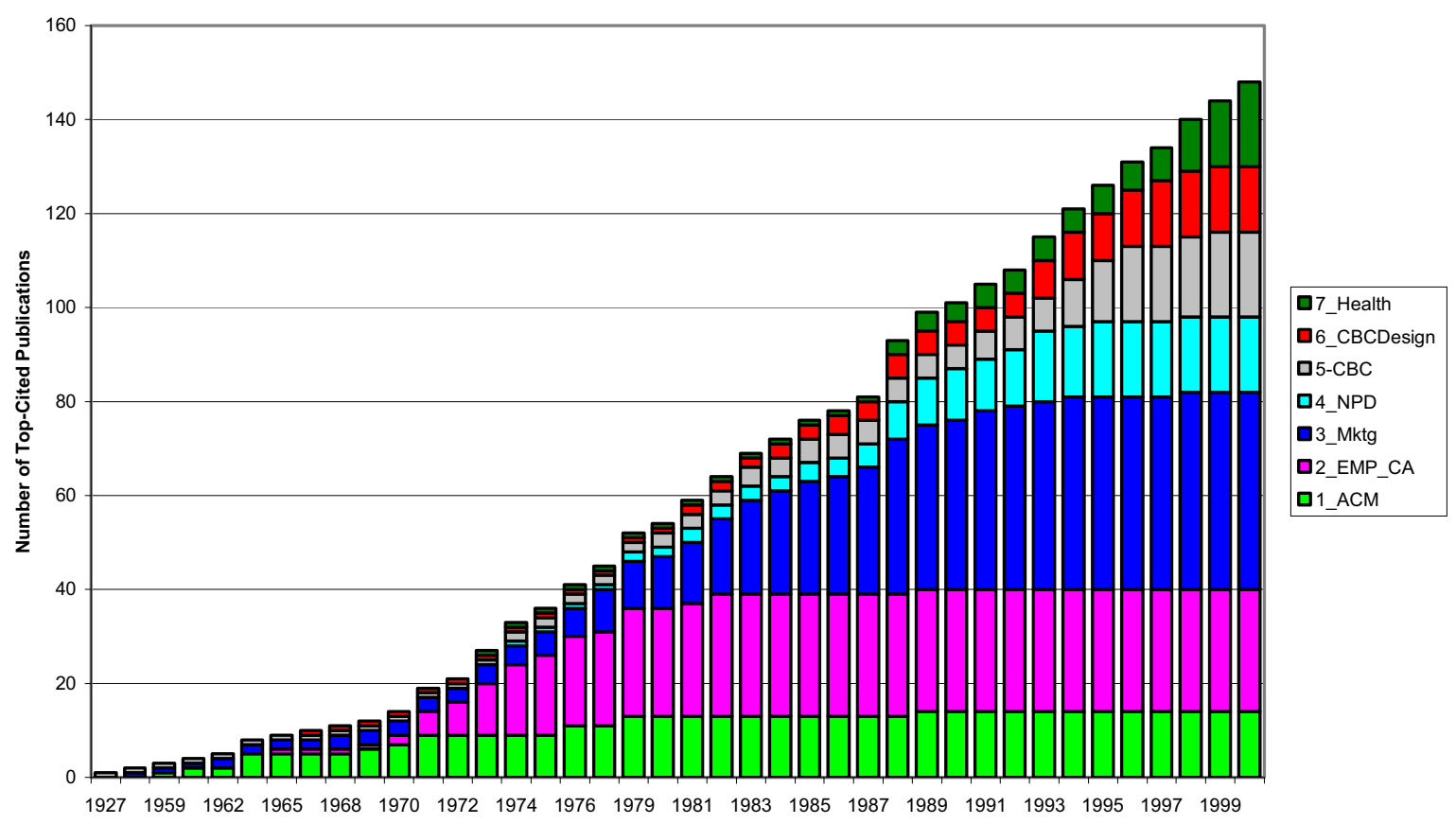

four, five, and six have developed almost coherently. The higher standard deviation in factor six indicates that the discourse on choice-based conjoint has succeeded in time peaks, whereas the discussion on underlying models for stated preferences (factor 5) showed a more constant discourse pattern over time.

Citation counts reveal that the discourse on CA applications in marketing (factor three) is the most cited. This seems plausible as this factor comprises the most important conjoint reviews that are relevant for both methodical- and application-based publications and consequently finds the highest echo in forthcoming publications. These results also correspond to the dominance of this factor shown by co-citation results. The first two discourses which contain the conceptual foundation of traditional CA also exhibit a high number of citations.

This underlines the high relevance of a two-sided conceptual foundation of CA: a theoretical perspective (factor one) and an empirical one (factor two). In addition, the high standard deviations of both factors indicate fluctuating citations over time. Publications were supposedly cited more frequently in "peaks" of traditional conjoint analytical research as shown in our diffusion analysis of conjoint analytical citations.

The most stable factor in regard to its relevance over the years (i.e. smallest standard deviation of times cited) is the discourse on new product development applications (factor four). This may be due to the fact that new product development constitutes an

Table 10: Timing and relevance of research streams

\begin{tabular}{lllllllll}
\hline & $\begin{array}{l}\text { Factor 1: } \\
\text { Axiomatic } \\
\text { CM }\end{array}$ & $\begin{array}{l}\text { Factor 2: } \\
\text { Empirical } \\
\text { CA }\end{array}$ & $\begin{array}{l}\text { Factor 3: } \\
\text { CA Market- } \\
\text { ing }\end{array}$ & $\begin{array}{l}\text { Factor 4: } \\
\text { CA for } \\
\text { NPD }\end{array}$ & $\begin{array}{l}\text { Factor 5: } \\
\text { Models for } \\
\text { CBC }\end{array}$ & $\begin{array}{l}\text { Factor 6: } \\
\text { CBC De- } \\
\text { sign }\end{array}$ & $\begin{array}{l}\text { Factor 7: } \\
\text { Health Ap- } \\
\text { plications }\end{array}$ & $\begin{array}{l}\text { Sample } \\
\text { Year of Publication }\end{array}$ \\
\hline Mean & 1971 & 1975 & 1983 & 1988 & 1992 & 1990 & 1995 & 1984 \\
\hline Std. dev. & 8.10 & 3.93 & 8.91 & 5.48 & 6.72 & 8.20 & 6.76 & 11.48 \\
\hline Count Citations & & & & & & & \\
\hline Mean & 29.21 & 29.15 & 36.24 & 19.38 & 23.72 & 19.00 & 25.89 & 28.09 \\
\hline Std.dev. $\quad 27.83$ & 22.16 & 48.51 & 8.08 & 13.98 & 8.22 & 13.45 & 30.41 \\
\hline
\end{tabular}


Figure 4: Received citations over time

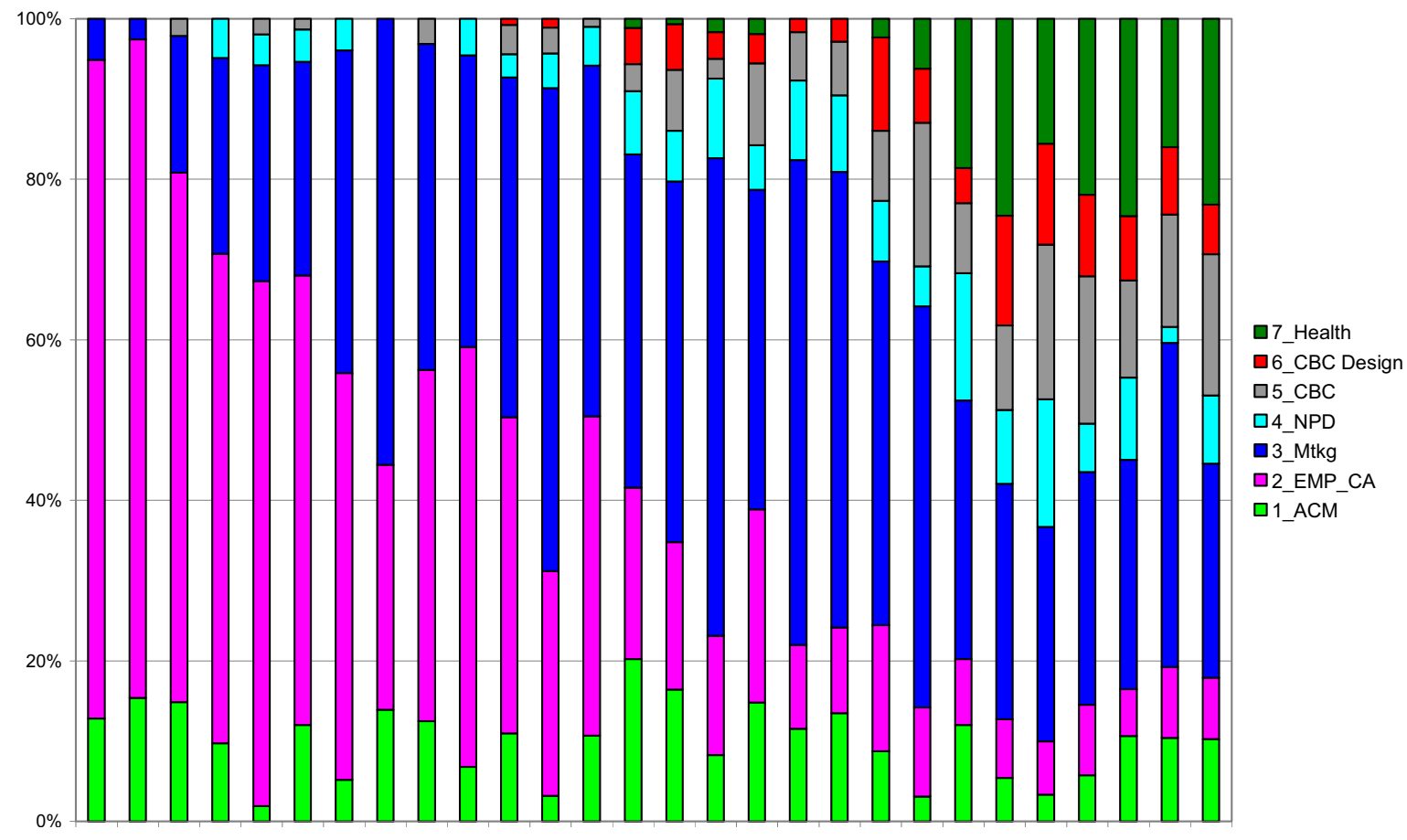

ongoing major application field of CA. Applications are likely to continuously cite "best conjoint practices" for showing the relevance of the method in real-world applications. On the other hand, new product development serves as a basis for further methodical conjoint advancements. Numerous recent conjoint analytical methods such as fast polyhedral methods or evolutionary conjoint rely on earlier works in this field and cite them consequently.

The homogeneous citation frequency observed in the design-related discourse on CBC (factor six) may be due to a closely connected community of scientists within this factor who have published many papers in collaboration. It seems plausible that respective works or common theoretic conceptualizations are steadily cited in such a community.

Looking at average time patterns, a timeline can be observed stemming from the first factor of axiomatic conjoint to the final factor of applications in health economics. Traditional conjoint analysis thus diffused from its conceptual basis to empirical applications primarily in marketing and subsequently focusing on new product development. Complementary hereto, choice-based conjoint is based on parallel developments on design and modelling in the early 1990 s and subsequently received an application focus in health economics.

To conclude our analyses, we integrate the time and the citation perspective. We calculate annually received citations stemming from our conjoint analytical data base and present the yearly distribution of received citations in Figure 4. The percentage values serve as indicator of the impact of the research streams over time.

The first two factors which constitute the theoretical foundations of conjoint have been cited less and less over time. Whereas in the beginning of conjoint analytical research these two factors constituted almost $100 \%$ of citations in CA, this picture naturally changed as later research streams were presented and established. Especially the impact of the discourse on empirical preference elicitation (factor two) has decreased over time. This shows that neither the theoretical nor the methodological foundation of CA as such has been questioned. Instead, publications that focus on application issues of $\mathrm{CA}$ (factor three) seem to be referred to as "conceptual foundation" of CA. The most important publications belong to those cited in the bibliography of conjointrelated studies as being indispensable. In contrast, citations of applications for new product development are quasi time-invariant and smaller in scale. The references to choice-based conjoint discourses (factors five, six, and seven) started in the early 9os and account for around 50\% of citations nowadays. While modelling and design issues for choice-based conjoint took off early on, applications in health 
economics have gained an amazingly high percentage of citations since 2000. This indicates a recent successful transfer of the method of Conjoint Analysis into a different scientific discipline.

\section{$7 \quad$ Summary and Conclusion}

Citation and co-citation patterns provided complementary information about the evolution of conjoint analysis: Whereas citations identified major contributions, co-citation reveals the relation between them. The bibliometric analysis thus provided insights into the drivers of the development and diffusion of $\mathrm{CA}$ as one of the most prominent marketing research methods. The results highlight that the discourse was not guided so much by theoretical considerations, but has relied and still relies on application issues whereby practical problems fostered the development of more sophisticated methodologies. This setting is most evidently underlined by the predominance of Paul Green who entered the discourse not from a theoretical perspective but from the context of his own market research experiences. Various citation as well as co-citation measures characterize him as the single most important promoter of CA who has contributed to various research streams simultaneously. Another key player, Jordan Louviere, shall be pointed out, as his work had a highly focused impact on the three discourses related to choice-based conjoint, characterizing him as a linking pin within this newer stream of research. Within each research stream, factor analytic measures provided further insights about the key drivers and most representative contributions of the specific discourses. Revealed ranking differences between factor scores and factor loadings discerned some fascinating insights not only about the direction of their scientific impact (inward or outward of specific research streams).

The chronological distribution both of published articles as well as received citations can be seen as clear evidence of a maturation stage, which the method of conjoint analysis has achieved by now. However, a revealed fragmentation of co-citation patterns into distinct subareas shows that there is still no coherent, "con-jointly" view on the method, but that various research streams co-exist only loosely coupled.

The factor analysis identifies seven distinct research streams which also indicate severe breakpoints in the academic discourse: Findings show that the discourse (1) on axiomatic utility modelling with conjoint measurement is separated from the subsequent discourse on (2) empirical preference elicitation with CA. This highlights a major break in the history of conjoint measurement, such that the proof of axiomatic foundations remained unsolved. Furthermore, a split into two basic experimental approaches can be observed: the (3) design of traditional CA for marketing applications and (6) design issues of choice-based conjoint and revealed preferences. Only the latter approach is revealed to be related to (5) modelling aspects of preference heterogeneity, which may forego such modelling chances for traditional CA. From an application point of view, (4) traditional applications in new product development and positioning reveal to be separated from (7) specific applications of choicebased conjoint in health care. Again, merging those separated views may provide some interesting potential for future contributions.

The seven research streams are however not fully separated from each other but interlinked. The time analysis shows that the origins of CA stem both from axiomatic considerations (factor 1) as well as its empirical operationalizations (factor 2). The complementary analysis of received citations indicates a strong reliance on subsequent applications in the overall marketing context (factor 3). Newer discourses on choice designs (6) and their applications in different contexts of health care (7) base on the design considerations of choice-based conjoint (6). To summarize, Figure 5 visualizes the dependencies and simplified path of the different research streams in a schematic way, thus simplifying the MDS-based results of the previous Figure 1.

So far we have seen an open (semi-)circular development stemming from axiomatic conjoint measurement. Given that basic theorems are still not verified and that a discussion has started recently about the adequacy of modelling variance and the error term, especially in choice-based conjoint analyses, it seems possible that we will encounter a more fundamental discussion about modelling issues in the future. It may well be the case that new methodological developments, such as e.g., in item response theory, will provide new impulses for such a discourse, linking together the various views on CA.

Certainly, this study has its limitations and provides potential for further studies as well. A major short- 
coming of the chosen approach is that citations are generally retrospective. Thus, actual papers are not always taken into account. Newer methods of the upcoming discipline of informetrics (Bar-Ilan 2008), especially the usage of real-time bibliometric data of the Internet, might help to better encompass applied for measuring perceived service quality. Thus, a careful interpretation of the reasoning of each articles occurrence is always needed for readers interested in single articles. This, however, does not seem to constitute a major drawback on the here-performed analysis of research streams at an

Figure 5: An evolution circle of conjoint analysis

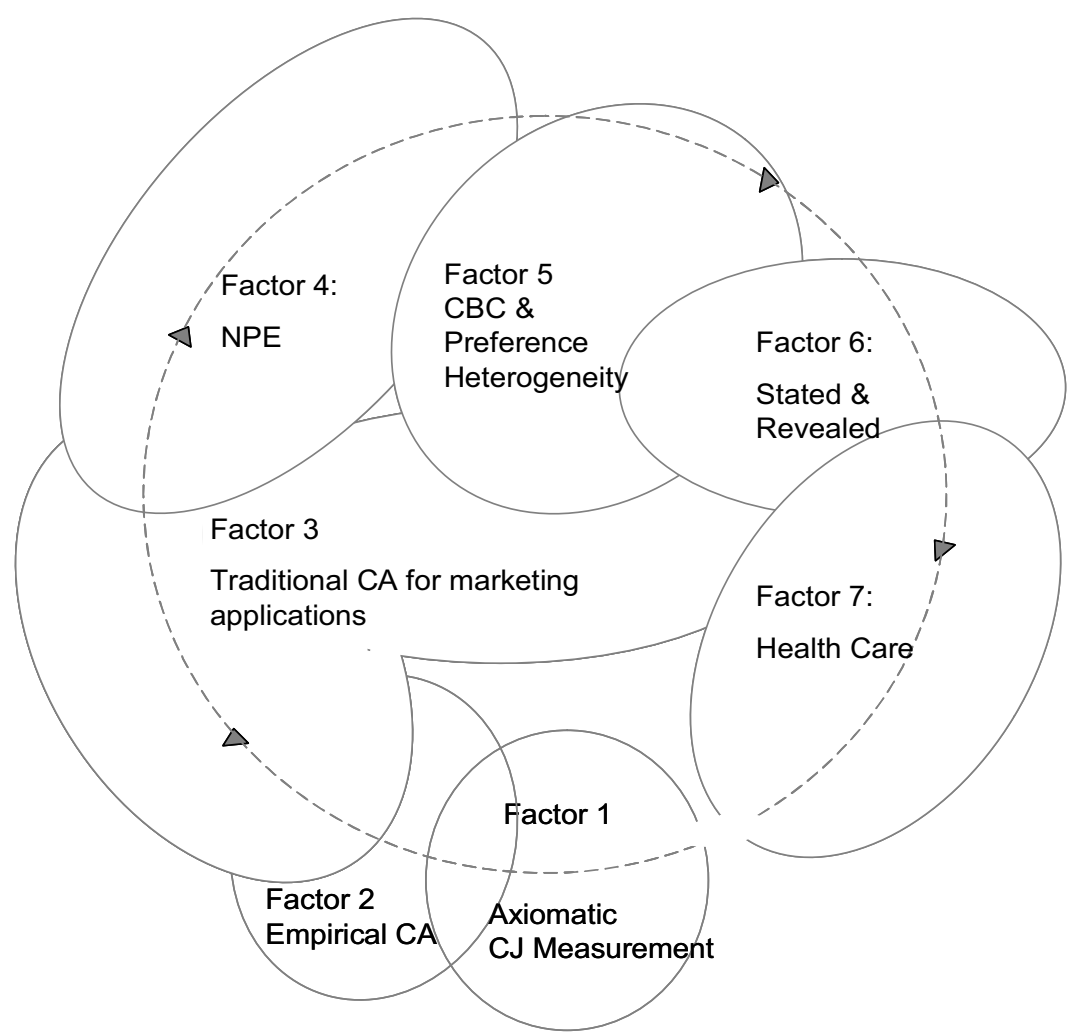

even the latest developments in scientific progress. The applied scheme only counts co-citations and does not value them: it is thus not differentiated whether an article is cited in a positive or negative sense. Articles may have been included in the analyses which are referenced without contributing to the conjoint discourse at all. This holds true for textbooks, which are likely to be referred to even if they do not provide any new contribution to the field. Furthermore, not all cited references necessarily deal with the CA as such. For example, the paper of Parasuraman, Zeithaml, and Berry (1985) which is peripherally allocated to the factor "Discourse on Applications of CA in Marketing" deals with ways for measuring service quality and is as such cited from subsequent conjoint researchers. This can be explained by the fact that conjoint analysis is often aggregate level: The discussed article of Parasuraman is one of the least important contributions both in terms of factor scores as well as factor loadings (see Table 5), which shows that the peripheral contribution of this article was well recovered by the method applied.

The analyses could finally be extended in various ways: At first, a regional differentiation of contributions might provide insights into geographic distributions of the various research streams (e.g., Polonsky and Carlson 2009) and diffusion of concepts. The interrelations between articles are by now limited to direct linkages, these could be expanded to an analysis of indirect linkages as well. This may help to better understand and measure the knowledge flow in between of research streams (e.g., Sivadas and Johnson 2005). 


\section{References}

Adamowicz, Wiktor L., Jordan J. Louviere, and Martin Williams (1994): Combining Revealed and Stated Preference Methods for Valuing Environmental Amenities, Journal of Environmental Economics and Management, 26 (3): 271-292.

Adamowicz, Wiktor L., Joffre D. Swait, Peter C. Boxall, Jordan J. Louviere, and Michael Williams (1997): Perceptions Versus Objective Measures of Environmental Quality in Combined Revealed and Stated Preference Models of Environmental Valuation, Journal of Environmental Economics and Management, 32 (1): 6584 .

Addelman, Sidney (1962): Orthogonal Main-Effect Plans for Asymmetrical Factorial Experiments, Technometrics, 4 (1): 21-46.

Allenby, Greg M., Neeraj Arora, and James Ginter (1995): Incorporating Prior Knowledge into the Analysis of Conjoint Studies, Journal of Marketing Research, 32 (2): 152-162.

Allenby, Greg M., Neeraj Arora, and James L. Ginter (1998): On the Heterogeneity of Demand, Journal of Marketing Research, 35 (3): 384-389.

Allenby, Greg M. and Peter E. Rossi (1999): Marketing Models of Consumer Heterogeneity, Journal of Econometrics, 89 (1-2): 5778.

Bar-Ilan, Judit (2008): Informetrics at the Beginning of the 21st Century - A Review, Journal of Informetrics, 2 (1): 1-52.

Baumgartner, Hans and Rik Pieters (2003): The Structural Influence of Marketing Journals: A Citation Analysis of the Discipline and its Subareas Over Time, Journal of Marketing, 67 (2): 123139.

Ben-Akiva, Moshe E. and Steven R. Lerman (1985): Discrete Choice Analysis, MIT Press: Cambridge.

Biehl, Markus, Henry Kim, and Michael Wade (2006): Relationships Among the Academic Business Disciplines: A Multi-Method Citation Analysis, Omega, 34 (4): 359-371.

Borgatti, Steve, Marin Everett, and Lin Freeman (2002): Ucinet 6 for Windows, Analytic Technologies: Harvard.

Boxall, Peter C., Wiktor L. Adamowicz, Joffre D. Swait, Michael Williams, and Jordan J. Louviere (1996): A Comparison of Stated Preference Methods for Environmental Valuation, Ecological Economics, 18 (3): 243-253.

Boyack, Kevin W., Katy Börner, and Richard Klavans (2009): Mapping the Structure and Evolution of Chemistry Research, Scientometrics, 79 (1): 45-60.

Carson, Richard T., Jordan J. Louviere, Donald A. Anderson, Phipps Arabie, David S. Bunch, David A. Hensher, Richard M. Johnson, Warren Kuhfeld, Dan Steinberg, Joffre D. Swait, Harry Timmermans, and James B. Wiley (1994): Experimental Analysis of Choice, Marketing Letters, 5 (4): 351-367.

Cattin, Philippe and Dick R. Wittink (1982): Commercial Use of Conjoint Analysis: A Survey, Journal of Marketing, 46 (3): 44-53.

Cote, Joseph A., Siew Meng Leong, and Jane Cote (1991): Assessing the Influence of Journal of Consumer Research: A Citation Analysis, Journal of Consumer Research, 18 (3): 402-410.

Culnan, Mary J. (1986): The Intellectual Development of Management Information Systems, 1972-1982: A Co-Citation Analysis, Management Science, 32 (2): 156-172.
Culnan, Mary J., Charles A. O'Reilly, and Jennifer A. Chatman (1990): Intellectual Structure of Research in Organisational Behavior, 1972-1984: A Cocitation Analysis, Journal of the American Society for Information Science, 41 (6): 453-458.

Debreu, Gerard (1960): Review of R. Duncan Luce: Individual Choice Behaviour: A Theoretical Analysis, American Economic Review, 50 (1): 186-188.

Elrod, Terry, Jordan J. Louviere, and Krishnakumar S. Davey (1992): An Empirical Comparison of Ratings-Based and ChoiceBased Conjoint Models, Journal of Marketing Research, 29 (3): 368-377.

Fishburn, Peter C. (1970): Intransitive Individual Indifference and Transitive Majorities, Econometrica, 38 (3): 482-489.

Garfield, Eugene (1979): Citation Indexing: Its Theory and Application in Science, Technology and Humanities, Wiley: New York.

Green, Paul E. (1984): Hybrid Models for Conjoint Analysis: An Expository Review, Journal of Marketing Research, 21 (2): 155169.

Green, Paul E., Stephen M. Goldberg, and Mila Montemayor (1981): A Hybrid Utility Estimation Model for Conjoint Analysis, Journal of Marketing, 45 (1): 33-41.

Green, Paul E. and Kristiaan Helsen (1989): Cross-Validation Assessment of Alternatives to Individual-Level Conjoint Analysis: A Case Study, Journal of Marketing Research, 26 (3): 346-350.

Green, Paul E. and Vithala R. Rao (1971): Conjoint Measurement for Quantifying Judgmental Data, Journal of Marketing Research, 8 (3): 355-363.

Green, Paul E. and V. Srinivasan (1978): Conjoint Analysis in Consumer Research: Issues and Outlook, Journal of Consumer Research, 5(2): 103-123.

Green, Paul E. and V. Srinivasan (1990): Conjoint-Analysis in Marketing - New Developments with Implications for Research and Practice, Journal of Marketing, 54 (4): 3-19.

Hauser, John R. and Vithala R. Rao (2004): Conjoint Analysis, Related Modeling and Applications, in: Yoram Wind and Paul E. Green (eds.): Marketing Research and Modeling, Progress and Prospect - A Tribute to Paul E. Green, Springer: Dordrecht, 141168.

Hensher, David A. (1994): Stated Preference Analysis of Travel Choices: The State of Practice, Transportation, 21 (2): 107-133.

Hoffman, Donna L. and Morris B. Holbrook (1993): The Intellectual Structure of Consumer Research: A Bibliometric Study of Author Cocitations in the First 15 Years of the Journal of Consumer Research, Journal of Consumer Research, 19 (4): 505-517.

Huber, Joel and Klaus Zwerina (1996): The Importance of Utility Balance in Efficient Choice Designs, Journal of Marketing Research, 33 (3): 307-317.

Hult, G. Tomas M. and Brian R. Chabowski (2008): Sourcing Research as an Intellectual Network of Ideas, Decision Sciences, 39 (3): 323-335.

Jarneving, Bo (2005): A Comparison of Two Bibliometric Methods for Mapping of the Research Front, Scientometrics, 65 (2): 245-263.

Jarneving, Bo (2008): A Variation of the Calculation of the First Author Cocitation Strength in Author Cocitation Analysis, Scientometrics, 77 (3): 485-504. 
Johnson, Richard M. (1987): Adaptive Conjoint Analysis, Proceedings of the Sawtooth Software Conference on Perceptual Mapping Conjoint Analysis and Computer Interviewing, Sawtooth Software: Ketchum, 254-265.

Kahneman, Daniel and Amos Tversky (1979): Prospect Theory: An Analysis of Decision under Risk, Econometrica, 47 (2): 263291.

Kohli, Rajeev and Ramesh Krishnamurti (1987): A Heuristic Approach to Product Design, Management Science, 33 (12): 15231533 .

Kohli, Rajeev and Ramesh Krishnamurti (1989): Optimal Product Design Using Conjoint Analysis: Computational Complexity and Algorithms, European Journal of Operational Research, 40 (2): 186-195.

Kohli, Rajeev and R. Sukumar (1990): Heuristics for Product-Line Design Using Conjoint Analysis, Management Science, 36 (12): 1464-1478.

Krantz, David H. and Amos Tversky (1971): Conjoint Measurement Analysis of Composition Rules in Psychology, Psychological Review, 78 (2): 151-169.

Kruskal, J. B. (1965): Analysis of Factorial Experiments by Estimating Monotone Transformations of the Data, Journal of the Royal Statistical Society. Series B (Methodological), 27 (2): 251263.

Leigh, Thomas W., David B. MacKay, and John O. Summers (1984): Reliability and Validity of Conjoint Analysis and SelfExplicated Weights: A Comparison, Journal of Marketing Research, 21 (4): 456-462.

Lenk, Peter J., Wayne S. DeSarbo, Paul E. Green, and Martin R. Young (1996): Hierarchical Bayes Conjoint Analysis: Recovery of Partworth Heterogeneity from Reduced Experimental Designs, Marketing Science, 15 (2): 173-191.

Leong, Siew Meng (1989): A Citation Analysis of the Journal of Consumer Research, Journal of Consumer Research, 15 (4): 492497.

Lievrouw, Leah (1990): Reconciling structure and process in the study of scholarly communication, in: C. L. Borgman (ed.): Scholarly Communication and Bibliometrics, Sage, Newbury Park, 5972.

Louviere, Jordan J. (1988): Conjoint Analysis Modelling of Stated Preferences: A Review of Theory, Methods, Recent Developments and External Validity, Journal of Transport Economics and Policy, 22 (1): 93-119.

Louviere, Jordan J., Thomas C. Eagle, and Steven H. Cohen (2005): Conjoint Analysis: Methods, Myths and Much More, Working Paper, University of Technology: Sydney.

Louviere, Jordan J., David A. Hensher, and Joffre D. Swait (2000): Stated Choice Methods: Analysis and Applications, Cambridge University Press: Cambridge U.K.

Louviere, Jordan J. and George Woodworth (1983): Design and Analysis of Simulated Consumer Choice or Allocation Experiments: An Approach Based on Aggregate Data, Journal of Marketing Research, 20 (4): 350-367.

Luce, R. Duncan and John W. Tukey (1964): Simultaneous Conjoint Measurement: A New Type of Fundamental Measurement, Journal of Mathematical Psychology, 1 (1): 1-27.
Ma, Zhenzhong, Yender Lee, and Kuo-Hsun Yu (2008): Ten Years of Conflict Management Studies: Themes, Concepts and Relationships, International Journal of Conflict Management, 19 (3): 234-248.

McBride, Richard D. and Fred S. Zufryden (1988): An Integer Programming Approach to the Optimal Product Line Selection Problem, Marketing Science, 7 (2): 126-140.

McCain, Katherine W. (1990): Mapping Authors in Intellectual Space: A Technical Overview, Journal of the American Society for Information Science, 41 (6): 433-443.

McFadden, Daniel (1974): Conditional Logit Analysis of Qualitative Choice Behaviour, in: Paul Zarembka (ed.): Frontiers in Econometrics, Academic Press: New York, 105-142.

Merton, Robert K. (1965): On the Shoulders of Giants: a Shandean Postscript, The Free Press: New York.

Nerur, Sridhar P., Abdul A. Rasheed, and Vivek Natarajan (2008): The Intellectual Structure of the Strategic Management Field: An Author Co-Citation Analysis, Strategic Management Journal, 29 (3): 319-336.

Parasuraman, A., Valerie A. Zeithaml, and Leonard L. Berry (1985): A Conceptual Model of Service Quality and Its Implications for Future Research, Journal of Marketing, 49 (4): 41-50.

Pieters, Rik, Hans Baumgartner, Jeroen Vermunt, and Tammo Bijmolt (1999): Importance and Similarity in the Evolving Citation Network of the International Journal of Research in Marketing, International Journal of Research in Marketing, 16 (2): 113127.

Pilkington, Alan and Jack Meredith (2009): The Evolution of the Intellectual Structure of Operations Management - 1980-2006: A Citation/Co-Citation Analysis, Journal of Operations Management, 27 (3): 185-202.

Pilkington, Alan and Thorsten Teichert (2006): Management of Technology: Themes, Concepts and Relationships, Technovation, 26 (3): 288-299.

Polonsky, Michael and Les Carlson (2009): Is there Global Inclusion of Authors in the Five Leading Advertising Journals? A Regional Comparison 1998-2007, International Journal of Advertising, 28 (4): 691-714.

Ponzi, Leonard J. (2002): The Intellectual Structure and Interdisciplinary Breadth of Knowledge Management: A Bibliometric Study of its Early Stage of Development, Scientometrics, 55 (2): 259-272.

Ramos-Rodriguez, Antoni-Rafael and José Ruiz-Navarro (2004): Changes in the Intellectual Structure of Strategic Management Research: A Bibliometric Study of the Strategic Management Journal, 1980-2000, Strategic Management Journal, 25 (10): 981-1004.

Roberts, Fred S. (1979): Measurement Theory, Addison-Wesley: New York.

Ryan, Mandy and Shelley Farrar (2000): Using Conjoint Analysis to Elicit Preferences for Health Care, British Medical Journal, 320 (7248): 1530-1533.

Ryan, Mandy and Jenny Hughes (1997): Using Conjoint Analysis to Assess Women's Preferences for Miscarriage Management, Health Economics, 6 (3): 261-273. 
Shocker, Allan D. and V. Srinivasan (1974): A Consumer-Based Methodology for Identification of New Product Ideas, Management Science, 20 (6): 921-937.

Shocker, Allan D. and V. Srinivasan (1979): Multiattribute Approaches for Product Concept Evaluation and Generation: A Critical-Review, Journal of Marketing Research, 16 (2): 159-18o.

Sivadas, Eugene and Mark S. Johnson (2005): Knowledge Flows in Marketing: An Analysis of Journal Article References and Citations, Marketing Theory, 5 (4): 339-361.

Small, Henry (1973): Co-Citation in the Scientific Literature: A New Measure of the Relationship between Two Documents, Journal of the American Society for Information Science, 24 (4): 265-269.

Small, Henry (2004): On the Shoulders of Robert Merton: Towards a Normative Theory of Citation, Scientometrics, 60 (1): 7179.

Small, Henry (2006): Tracking and Predicting Growth Areas in Science, Scientometrics, 68 (3): 595-610.

Srinivasan, V. and Allan D. Shocker (1973): Estimating the Weights for Multiple Attributes in a Composite Criterion Using Pairwise Judgments, Psychometrika, 38 (4): 473-493.

Swait, Joffre D. and Jordan J. Louviere (1993): The Role of the Scale Parameter in the Estimation and Comparison of Multinomial Logit Models, Journal of Marketing Research, 30 (3): 305314.

Tahai, Alireza and Michael J. Meyer (1999): A Revealed Preference Study of Management Journals' Direct Influences, Strategic Management Journal, 20 (3): 279-296.

Teichert, Thorsten (2004): Mapping Research in Innovation Management: A Bibliometric Analysis of Research Policy, in: Sönke Albers (ed.): Cross-Functional Innovation Management: Perspectives from Different Disciplines, Gabler: Wiesbaden, 369388.

Tversky, Amos (1969): Intransitivity of Preferences, Psychological Review, 76 (1): 31-48.

Tversky, Amos and Eldar Shafir (1992): Choice Under Conflict: The Dynamics of Deferred Decision, Psychological Science, 3 (6): 358-361.
Vriens, Marco, Harmen Oppewal, and Michel Wedel (1998): Ratings-Based versus Choice-Based Latent Class Conjoint Models - An Empirical Comparison, Journal of the Market Research Society, 40 (3): 237-248.

White, Howard D. (1990): Author Cocitation Analysis: Overview and Defense, in: Christine L. Borgman (ed.): Scholarly Communication and Bibliometrics, Sage: Newbury Park, 84-106.

White, Howard D. (2004): Citation Analysis and Discourse Analysis Revisited, Applied Linguistics, 25 (1): 89-116.

White, Howard and Belver C. Griffith (1981): Author Cocitation: A Literature Measure of Intellectual Structure, Journal of the American Society for Information Science, 32 (3): 163-172.

White, Howard D. and Katherine W. McCain (1998): Visualizing a Discipline: An Author Co-Citation Analysis of Information Science, 1972-1995, Journal of the American Society for Information Science, 49 (4): 327-355.

Wittink, Dick R. and Philippe Cattin (1989): Commercial Use of Conjoint Analysis: An Update, Journal of Marketing, 53 (3): 9196.

Zinkhan, George M., Martin S. Roth, and Mary Jane Saxton (1992): Knowledge Development and Scientific Status in Consumer-Behavior Research: A Social-Exchange Perspective, Journal of Consumer Research, 19 (2): 282-291.

\section{Biographies}

Thorsten Teichert holds the Chair of Marketing and Innovation at the University of Hamburg and is Visiting Professor at the University of Technology, Sydney. Research topics and consulting projects include issues of new product development, global innovation management as well as issues of consumer behavior.

Edlira Shehu is working as a specialist for predictive analytics and data mining at Hamburger Sparkasse AG in Hamburg. Her research interests are application of choice models, preference elicitation techniques as well as analytical customer relationship management. She was research assistant at the Chair of Marketing and Innovation at the University of Hamburg. 